\title{
Spatio-Temporal Variability of Summer Monsoon Onset over Pakistan
}

\author{
Shaukat Ali ${ }^{1,2} \cdot$ Bushra Khalid $^{2,3,4} \cdot$ Rida Sehar Kiani $^{4} \cdot$ Romaisa Babar $^{4} \cdot$ Sana Nasir ${ }^{4}$ Nadia Rehman ${ }^{1}$. \\ Muhammad Adnan ${ }^{1}$. Muhammad Arif Goheer ${ }^{1}$
}

Received: 5 December 2018 / Revised: 29 April 2019 / Accepted: 2 May 2019 / Published online: 27 June 2019

(C) The Author(s) 2019

\begin{abstract}
Pakistan receives huge amount of rainfall during summer monsoon season that provides water replenishment for transition periods, helps in maintaining natural and anthropogenic ecosystems, and increased crop productivity. In this changing world, shifts in summer monsoon onset in Pakistan have been observed that seems to affect the society in general. Therefore, it is vital to address these summer monsoon onset shifts to help policy makings and implementation. The study was carried out to analyse the spatio-temporal variability in summer monsoon onset in four objectively defined regions covering all Pakistan. A total of 35 meteorological stations spreading over four regions (i.e., northern, central east, central west, and southern) were taken in to account and shifts in summer monsoon onset have been calculated for the period of 1971-2010. The analysis is based on the observational data of daily precipitation from 20th Jun-20th July for 40 years. The onset for each year and mean onset for each decade has been calculated for all stations. The data was analysed for homogeneity, spatial and temporal variability of monsoon rainfall has been calculated for all four regions, and station wise monsoon onset has been discussed in detail. The temporal analysis shows that the onset of monsoon has shift towards earlier onset from first week of July to last week of June at most of the stations in which the investigation was carried out during the studied period. The spatial analysis shows that the amount of monsoon precipitation during the onset period has decreased after 1970's in almost all regions. This variability in monsoon onset can have major impacts on rain fed agriculture and cultivation of crops like maize, soybean, rice and sugarcane etc. and will have to revisit the cropping calendar.
\end{abstract}

Keywords Monsoon onset $\cdot$ Spatial variability $\cdot$ Temporal variability $\cdot$ Asian summer monsoon $\cdot$ Monsoon shifts

Highlights 1-Observations at 35 meteorological stations were processed for summer monsoon onset in Pakistan

2- Temporal analysis of four decades i.e., 1971-2010

3- Mean monsoon onset has observed a shift over 40 years to an earlier time in Pakistan

4- Total amount of precipitation has decreased over the studied period

5- North eastern region of Pakistan received highest amount of precipitation among all others

Responsible Editor: Ashok Karumuri.

Bushra Khalid

kh_bushra@yahoo.com

1 Global Change Impact Studies Centre, Ministry of Climate Change, Islamabad, Pakistan

2 Earth System Physics, The Abdus Salam International Centre for Theoretical Physics, Trieste, Italy

3 International Institute for Applied Systems Analysis, Laxenburg, Austria

4 Department of Environmental Science, International Islamic University, Islamabad, Pakistan

\section{Introduction}

The summer monsoon over Pakistan is part of the bigger Asian Summer Monsoon (ASM) circulation system. The ASM onset generally occurs by June 1 at the southernmost peninsula and progresses towards the most northwestern region in India by mid-July. The ASM withdraws from the northwest and southernmost peninsula by September 1 and mid-October respectively (Singh and Ranade 2010). According to IMD (1943), the presence of a continued warming tendency and positive radiation balance of the northern hemisphere cause the progression of monsoon over northwest India and Pakistan. The ASM passes through the Indian mainland, further advances northwest and enters central Pakistan from 5 July-24 July (Ding and Sikka 2006; Singh and Ranade 2010). The southwest flow of ASM officially begins the Pakistan's rainy season (Latif and Syed 2015). The general trend of the South Asian monsoon, its begin and end, its movement over different regions within South Asia 
has been thoroughly discussed in scientific literature (c.f. Krishnamurti 1985; Webster and Lukas 1992; Lau et al. 2000; Ding and Chan 2005; Bhat et al. 2002; Johnson et al. 2004; Webster 2005; Singh and Ranade 2010; Saeed et al. 2011; Imran et al. 2014; Rasul and Chaudhry 2010). The summer monsoon rainfall over the subcontinent has great social, agricultural, and economic value (Ahmad et al. 2014). The summer monsoon contributes $65-75 \%$ of the total annual rainfall in Pakistan (Ahmad et al. 2014). The summer monsoon rainfall in Pakistan provides water replenishment which allows the water requirements to be fulfilled during the transition period until the onset of winter rainfall (Imran et al. 2014). Summer monsoon rainfall is of vital importance for anthropogenic and natural ecosystems of the region (Singh and Ranade 2010).

Date of monsoon onset over Pakistan is important from the perspective of agricultural yield (Imran et al. 2014). The agricultural sector of Pakistan accounts for $24 \%$ of total Gross Domestic Product (GDP) (IUCN 2009). Small variations in monsoon onset may have adverse impacts on agricultural productivity that in turn may have negative impacts on GDP (Latif and Syed 2015). In monsoon dependent regions, crop productivity is mainly determined by the onset even if the mean rainfall during summer season remains normal (Latif and Syed 2015). Rashid and Rasul (2011) discussed the maize crop which is cultivated with the onset of monsoon and becomes mature when the monsoon season ends by September in Pakistan. The maize crop is highly sensitive to moisture surplus and deficit. The yield decreases if the rainfall exceeds the peak value $300 \mathrm{~mm}$. If the monsoon onset is delayed, it affects the crop as deficient soil moisture cannot sustain seed germination and growth (Rashid and Rasul 2011).

The variation in the standard deviation of monsoon onset is larger over Pakistan (i.e., 11-12 days) as compared to India (i.e., 7-8 days) (Latif and Syed 2015; Fasullo and Webster 2003; Raju et al. 2005; Pai and Nair 2009; Wang et al. 2009; Puranik et al. 2013). The monsoon onset in Pakistan may be significantly delayed due to El Nino Southern Oscillation (ENSO) (Latif and Syed 2015). The north-eastern belt of Pakistan including stations of Lahore, Sialkot, Jhelum and Islamabad receive the first rainfall as the summer monsoon system enters in the country after deflecting from the great Himalayas and travelling along the foothills. At the same time, southwest winds from the Arabian Sea progress toward Pakistan and the first monsoon rainfall prevails over Chhor and Badin stations, making it the south-eastern belt of summer monsoon (Imran et al. 2014). The onset of summer monsoon over India has been investigated in several studies (c.f. Shamshad 1988; Ananthakrishnan and Soman 1988; Raju et al. 2005; Joseph et al. 2006; Simon et al. 2006; Cook and Buckley 2009; Kumar et al. 2009). A few studies are present in scientific literature discussing the monsoon onset over Pakistan; some studies discussed over all monsoon onset situation in Pakistan (e.g., IMD 1943; Singh and Ranade 2010; Latif and Syed 2015; Rasul and Chaudhry 2010; Sadiq and Qureshi 2010), and a few studies discussed monsoon onset for selected cities only (e.g., Imran et al. 2014). However, there is a limitation in these studies from the perspective of spatial and temporal variability in monsoon onset covering all stations and all regions separately in the Pakistan. This study provides comprehensive analysis of monsoon onset over different meteorological stations as well as different regions of Pakistan which form the basis for the trends in future projection of monsoon variability in the country. The onset of summer monsoon over the Core Monsoon Region of Pakistan (CMRP) has been discussed by Latif and Syed, (2015) using observational daily rainfall and Perceptible Water (PW) data sets. An objective criterion is proposed to define monsoon onset dates by employing Precipitation Index and Normalized Perceptible Water Index techniques. The result of the study shows that the seasonal transition from premonsoon to the monsoon season occurs in the end of June or the start of July. The mean onset date determined through station data is July 1 with a standard deviation of about 12 days over the CMRP. The other data sets APHRODITE and NVAP$\mathrm{M}$ both exhibit onset date as 30 June with standard deviation of 11.7 and 10.5 days, respectively. Although, PW-based climatological mean onset date is very similar to the rainfallbased mean onset date but onset dates on annual basis are varying.

The spatial and temporal variation in summer monsoon onset has not been studied extensively in Pakistan. Therefore, this study intends to present the spatio-temporal variability of summer monsoon onset over 35 meteorological stations consists of four different regions of Pakistan. The analysis was done for the period of 1971-2010 and decade wise monsoon onset has been discussed. An overall temporal shift in summer monsoon onset has been analyzed. The spatial variability analysis involves Inverse Distance Weighted (IDW) interpolation to show the rainfall distributions over Pakistan during the monsoon onset for 40 years. While temporal variability assessment is carried out on individual stations as well as based on four regions of Pakistan.

\section{Material and Methods}

\subsection{Study Region}

Pakistan is located between $23.35^{\circ} \mathrm{N}$ to $37.50^{\circ} \mathrm{N}$ latitude and extends from $60.50^{\circ} \mathrm{E}$ to $77.50^{\circ} \mathrm{E}$ longitude. A large part of Pakistan is characterized by spatial and temporal variability in climate. The climate of Pakistan is influenced by its topographic features. Pakistan lies on the northern part of southwest monsoon currents in the subcontinent, on the western frontier of the ASM, on the fringe of western disturbances 
entering the subcontinent from the far west. The southern plains of Pakistan are almost arid. The Baluchistan province and north-eastern mountains have arid highland climate. The desert and arid region of Pakistan are the eastern limit of south Asia and one of the world's largest dry regions. In the region of northern mountains, the mean annual precipitation is quite insufficient for natural vegetation (Shamshad 1988). The huge amount of total annual rainfall in Pakistan is received during the summer monsoon season.

To carry out this study the map of Pakistan was divided into four regions namely Region I (North), Region II (Central East), Region III (Central West) and Region IV (South) (Fig. 1). Total 35 meteorological stations were selected spreading over these four regions. Pakistan has a very diverse topography due to which different climatic conditions prevail in different parts of the country. The division in this study is made based on climatology and weather conditions, extent of monsoon system penetrating, and amount of precipitation received during monsoon season in these regions of Pakistan. Region I is the northern part of Pakistan comprised of mountains and glaciers with different temperature and precipitation patterns as compared to the rest of the country. Region II comprises monsoon dominated part of Pakistan which receives maximum amount of rainfall during the summer monsoon season. Region III is the part where monsoon penetrates to a greater degree but far less than the Region II. The stations lying in Region IV receive monsoon from south western winds from Arabian Sea, however, the amount of rainfall is quite less as compared to Region II and Region III. The abovementioned division was made based on different climatic conditions of the regions and is shown in Fig. 1. All the stations selected for study have their own importance because of their geographical location. The selected stations and their division into regions are listed in the Table 1.

\subsection{Data Acquisition}

The climatic data used in this study was collected from Pakistan Meteorological Department (PMD). This data involves the daily observational precipitation $(\mathrm{mm})$ for the months of June and July for 35 stations that are in different areas ranging from north to south of the country as shown in Fig. 1. The data used in this study covered a time period of 40 years i.e., 1971-2010. To get an overall view of the

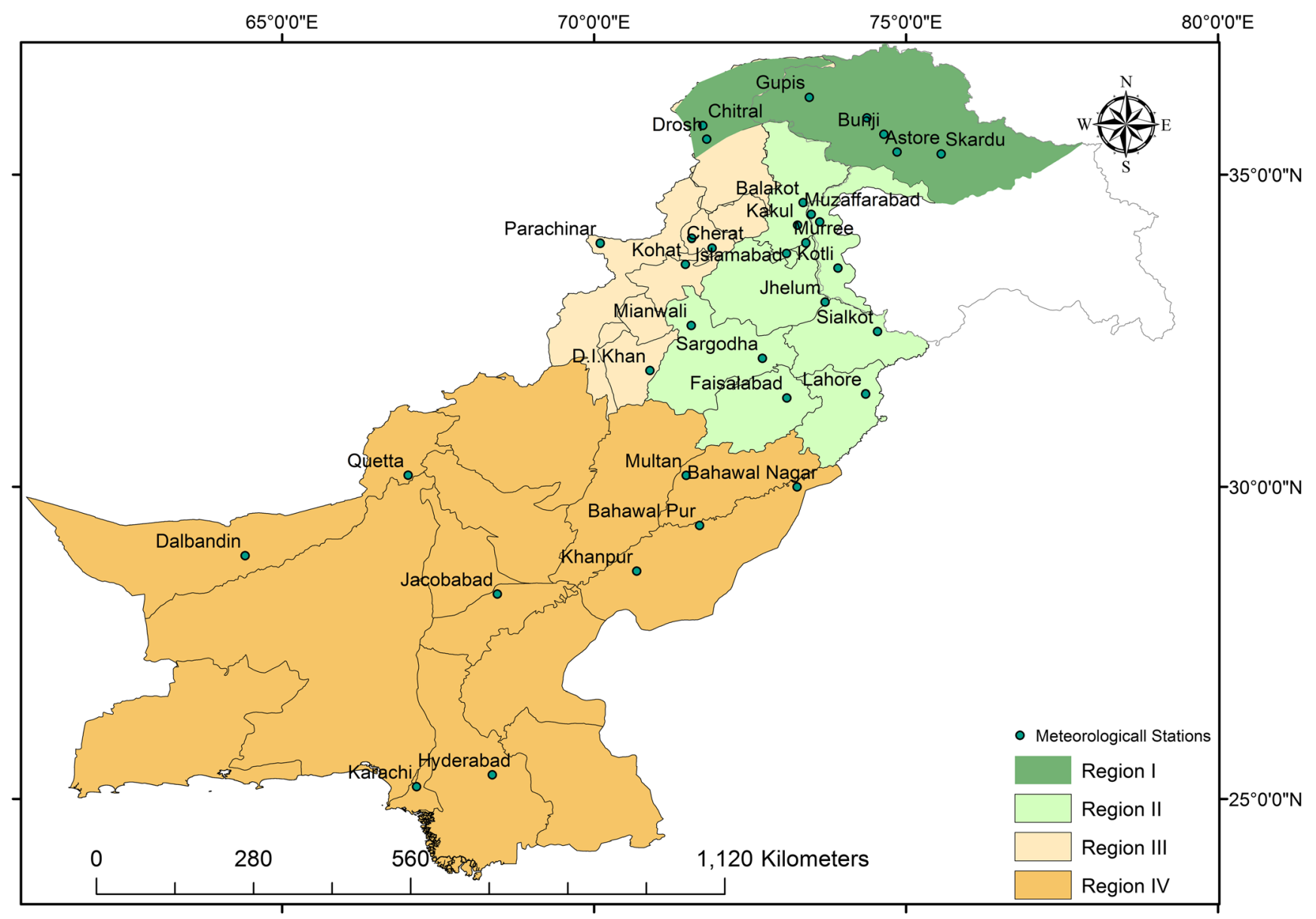

Fig. 1 Map of study area showing the selected meteorological stations in different regions of Pakistan 
Table 1 Selected meteorological stations with their division into four regions

\begin{tabular}{|c|c|c|c|c|c|}
\hline Sr. No. & Station & Latitude & Longitude & Elevation/Height a.m.s.l. & Region \\
\hline 1. & Drosh & $35^{\circ} 33^{\prime} 29^{\prime \prime} \mathrm{N}$ & $71^{\circ} 47^{\prime} 33^{\prime \prime} \mathrm{E}$ & $1463.90 \mathrm{~m}$ & North \\
\hline 2. & Chitral & $35^{\circ} 50^{\prime} 30^{\prime \prime} \mathrm{N}$ & $71^{\circ} 46^{\prime} 54^{\prime \prime} \mathrm{E}$ & $1497.8 \mathrm{~m}$ & North \\
\hline 3. & Gupis & $36^{\circ} 14^{\prime} 0 " \mathrm{~N}$ & $73^{\circ} 26^{\prime} 0^{\prime \prime} \mathrm{E}$ & $2156.0 \mathrm{~m}$ & North \\
\hline 4. & Gilgit & $35^{\circ} 16^{\prime} 55.0812^{\prime \prime} \mathrm{N}$ & $74^{\circ} 50^{\prime} 30.9912^{\prime \prime} \mathrm{E}$. & $1460.0 \mathrm{~m}$ & North \\
\hline 5. & Bunji & $35^{\circ} 16^{\prime} 55.0812^{\prime \prime} \mathrm{N}$ & $74^{\circ} 50^{\prime} 30.9912^{\prime \prime} \mathrm{E}$. & $1372.0 \mathrm{~m}$ & North \\
\hline 6. & Astore & $35^{\circ} 02^{\prime} 12.18^{\prime \prime} \mathrm{N}$ & $75^{\circ} 06^{\prime} 22.14^{\prime \prime} \mathrm{E}$. & $2168.0 \mathrm{~m}$ & North \\
\hline 7. & Skardu & $35^{\circ} 17^{\prime} 59^{\prime \prime} \mathrm{N}$ & $75^{\circ} 37^{\prime} 0^{\prime \prime} \mathrm{E}$ & $2317.0 \mathrm{~m}$ & North \\
\hline 8. & Balakot & $34^{\circ} 32^{\prime} 22.7940^{\prime \prime} \mathrm{N}$ & $73^{\circ} 21^{\prime} 0.8460^{\prime \prime} \mathrm{E}$. & $995.40 \mathrm{~m}$ & Central East \\
\hline 9. & Kakul & $34^{\circ} 11^{\prime} 0 " \mathrm{~N}$ & $73^{\circ} 16^{\prime} 0^{\prime \prime} \mathrm{E}$ & $1308.0 \mathrm{~m}$ & Central East \\
\hline 10. & Muzaffarabad & $34^{\circ} 21^{\prime} 34.8768^{\prime \prime} \mathrm{N}$ & $73^{\circ} 28^{\prime} 15.7944^{\prime \prime} \mathrm{E}$ & $702.0 \mathrm{~m}$ & Central East \\
\hline 11. & G-dupatta & $34^{\circ} 13^{\prime} 17.4^{\prime \prime} \mathrm{N}$ & $73^{\circ} 36^{\prime} 57^{\prime \prime} \mathrm{E}$ & $813.5 \mathrm{~m}$ & Central East \\
\hline 12. & Murree & $33^{\circ} 54^{\prime} 27.98^{\prime \prime} \mathrm{N}$ & $73^{\circ} 23^{\prime} 29.4^{\prime \prime} \mathrm{E}$ & $2167 \mathrm{~m}$ & Central East \\
\hline 13. & Kotli & $33^{\circ} 31^{\prime} 0.01^{\prime \prime} \mathrm{N}$ & $73^{\circ} 55^{\prime} 0.01^{\prime \prime} \mathrm{E}$ & $614.0 \mathrm{~m}$ & Central East \\
\hline 14. & Islamabad & $33^{\circ} 44^{\prime} 16.9620^{\prime \prime} \mathrm{N}$ & $73^{\circ} 5^{\prime} 4.1568^{\prime \prime} \mathrm{E}$ & $507 \mathrm{~m}$ & Central East \\
\hline 15. & Jehlum & $32^{\circ} 56^{\prime} 25.9728^{\prime \prime} \mathrm{N}$ & $73^{\circ} 43^{\prime} 39.4716^{\prime \prime} \mathrm{E}$ & $287.19 \mathrm{~m}$ & Central East \\
\hline 16. & Sialkot & $32^{\circ} 29^{\prime} 33.65^{\prime \prime} \mathrm{N}$ & $74^{\circ} 31^{\prime} 52.82^{\prime \prime} \mathrm{E}$ & $255.1 \mathrm{~m}$ & Central East \\
\hline 17. & Lahore & $31^{\circ} 34^{\prime} 55.3620^{\prime \prime} \mathrm{N}$ & $74^{\circ} 19^{\prime} 45.7536^{\prime \prime} \mathrm{E}$ & $214.00 \mathrm{~m}$ & Central East \\
\hline 18. & Faisalabad & $31^{\circ} 25^{\prime} 15.7620^{\prime \prime} \mathrm{N}$ & $73^{\circ} 5^{\prime} 21.4584^{\prime \prime} \mathrm{E}$ & $185.6 \mathrm{~m}$ & Central East \\
\hline 19. & Sargodha & $32^{\circ} 4^{\prime} 56.8776^{\prime \prime} \mathrm{N}$ & $72^{\circ} 40^{\prime} 8.8608^{\prime \prime} \mathrm{E}$. & $187 \mathrm{~m}$ & Central East \\
\hline 20. & Parachinar & $33^{\circ} 53^{\prime} 1.29^{\prime \prime} \mathrm{N}$ & $70^{\circ} 6^{\prime} 35.49^{\prime \prime} \mathrm{E}$ & $1725.00 \mathrm{~m}$ & Central West \\
\hline 21. & Peshawar & $34^{\circ} 1^{\prime} 33.3012^{\prime \prime} \mathrm{N}$ & $71^{\circ} 33^{\prime} 36.4860^{\prime \prime} \mathrm{E}$. & $327 \mathrm{~m}$ & Central West \\
\hline 22. & Cherat & $33^{\circ} 50^{\prime} 2.04^{\prime \prime} \mathrm{N}$ & $71^{\circ} 51^{\prime} 2.58^{\prime \prime} \mathrm{E}$ & $1372.0 \mathrm{~m}$ & Central West \\
\hline 23. & Kohat & $33^{\circ} 36^{\prime} 4.0608^{\prime \prime} \mathrm{N}$ & $71^{\circ} 26^{\prime} 41.2008^{\prime \prime} \mathrm{E}$. & $503 \mathrm{~m}$ & Central West \\
\hline 24. & D.I Khan & $31^{\circ} 49^{\prime} 53.3352^{\prime \prime} \mathrm{N}$ & $70^{\circ} 54^{\prime} 41.7528^{\prime \prime} \mathrm{E}$ & $171.20 \mathrm{~m}$ & Central West \\
\hline 25. & Mianwali & $32^{\circ} 35^{\prime} 7.48^{\prime \prime} \mathrm{N}$ & $71^{\circ} 32^{\prime} 37.02^{\prime \prime} \mathrm{E}$ & $210 \mathrm{~m}$ & Central West \\
\hline 26. & Bahawalnagar & $29^{\circ} 59^{\prime} 57.06^{\prime \prime} \mathrm{N}$ & $73^{\circ} 15^{\prime} 31.84^{\prime \prime} \mathrm{E}$ & $161.05 \mathrm{~m}$ & South \\
\hline 27. & Multan & $30^{\circ} 10^{\prime} 34.1652^{\prime \prime} \mathrm{N}$ & $71^{\circ} 27^{\prime} 14.5728^{\prime \prime} \mathrm{E}$. & $121.95 \mathrm{~m}$ & South \\
\hline 28. & Bahawalpur & $29^{\circ} 25^{\prime} 5.0448^{\prime \prime} \mathrm{N}$ & $71^{\circ} 40^{\prime} 14.4660^{\prime \prime} \mathrm{E}$. & $110.00 \mathrm{~m}$ & South \\
\hline 29. & Khanpur & $26^{\circ} 59^{\prime} 53.01^{\prime \prime} \mathrm{N}$ & $67^{\circ} 41^{\prime} 32.29^{\prime \prime} \mathrm{E}$ & $88.41 \mathrm{~m}$ & South \\
\hline 30. & Jaccobabad & $28^{\circ} 16^{\prime} 58.57^{\prime} \mathrm{N}$ & $68^{\circ} 26^{\prime} 11.36^{\prime \prime} \mathrm{E}$ & $55 \mathrm{~m}$ & South \\
\hline 31. & Hyderabad & $31^{\circ} 20^{\prime} 30.4692^{\prime \prime} \mathrm{N}$ & $71^{\circ} 41^{\prime} 49.1964^{\prime \prime} \mathrm{E}$ & $28 \mathrm{~m}$ & South \\
\hline 32. & Zoab & $31^{\circ} 09^{\prime} 60.00^{\prime \prime} \mathrm{N}$ & $68^{\circ} 49^{\prime} 59.99^{\prime \prime} \mathrm{E}$ & $1405 \mathrm{~m}$ & South \\
\hline 33. & Quetta & $30^{\circ} 11^{\prime} \mathrm{N}$ & $66^{\circ} 57^{\prime} \mathrm{E}$ & $1626 \mathrm{~m}$ & South \\
\hline 34. & Dalbadin & $28^{\circ} 53^{\prime} \mathrm{N}$ & $64^{\circ} 24^{\prime} \mathrm{E}$ & $848 \mathrm{~m}$ & South \\
\hline 35. & Karachi & $24^{\circ} 54^{\prime} \mathrm{N}$ & $66^{\circ} 56^{\prime} \mathrm{E}^{\prime}$ & $22 \mathrm{~m}$ & South \\
\hline
\end{tabular}

Pakistan Meteorological Department

precipitation of the selected stations, statistical analysis was carried out. The total/average annual precipitation $(\mathrm{mm})$ and total/average monsoon precipitation (mm) (June-Sep) of the selected stations was calculated for the period of 1971-2010.

\subsection{Homogeneity Test}

Homogeneity test is used to detect the variability in data series. In general, when the data is homogeneous, it means that the measurements of the data are taken at a time with the same instruments and in same environments. According to Kang and Yusof (2012) it is difficult to deal with rainfall data because environmental characteristics and structures, changes in measurement techniques and location of stations affect the observations. Since, the data used in current study is observational, so it was important to check the homogeneity of the data before carrying out analysis. Karabork et al. (2007) described two classifications of the homogeneity tests of time series i.e., 'absolute method' and 'relative method'. In relative method, testing process is carried out in neighbouring stations while in absolute method, each station is tested individually (Chang et al. 2017). Relative method detects inhomogeneity 
easily however, this method does not distinguish between the real changes and the random fluctuations of the observations (Peterson et al. 1998). In this study, we used the 'absolute method' to detect inhomogeneity in which the test is applied separately for each station (e.g., Wijngaard et al. 2003) to distinguish between the real changes and random fluctuations of the observations. Using the absolute method, the homogeneity of the total precipitation of the period 20th June -20th July of each station was tested by using Pettitt's Test from 1971 to 2010. Pettitt's test is a nonparametric test developed by Pettit, (Pettitt 1979), is quite helpful in detecting the occurrence of abrupt changes in climatic data (Smadi and Zghoul 2006). Homogeneity test is generally used to identify a single change-point in continuous data sets such as climate series or hydrological series. The results of the test for each station were evaluated for a significance level of 5\% to detect inhomogeneities. To minimize the error in analysis, standard deviation of onset time was also calculated. The results of homogeneity test were evaluated based on different classes. These classes were made according to the study of Wijngaard et al. (2003). The classification described by Wijngaard et al. (2003) was based on number of tests rejecting the null hypothesis. As present study involved Pettitt's test therefore two classes were identified and are as follows:

Class A: It refers to data that is useful in which none of the test rejects the null hypothesis. The series seem to be adequately homogeneous for further analysis.

Class B: It refers to data that is doubtful in which test rejects the null hypothesis. It means that there is indication of inhomogeneity. Thus, the results of further analysis should be observed critically from the perspective of existence of possible in-homogeneities.

\subsection{Temporal Analysis of Monsoon Onset}

World Meteorological Organization (WMO) has described monsoon onset as Pentad criteria i.e., "the five day mean rainfall averaged over calendar day intervals of five days is called pentad rainfall" (Compendium of Meteorology 1979). To determine the onset of summer monsoon in 35 meteorological stations of Pakistan, daily precipitation data for 31 days i.e., 20th June to 20th July for the years of 1971-2010 was assembled. The reason to select this 31-day window is the seasonal transition from pre-monsoon to the monsoon season that occurs in the end of June to the start of July. The mean onset date determined through different studies is start of July with a standard deviation of about 12 days (Latif and Syed 2015). Hence, the onset of monsoon on different stations in Pakistan is likely to occur from 20th June to 20th July. To calculate the temporal shift in the monsoon onset in Pakistan, the onset date of each individual year from 1971 to 2010 for all the stations was determined. As different parts of the country receive variable amount of monsoon precipitation, the whole country was divided into four regions based on the amount of monsoon precipitation it receives (Table 1). The criteria used to determine the onset date varied with each region and is based on previous studies (c.f. Latif and Syed 2015; Faisal and Sadiq 2012), with some modifications (Table 2).

\subsection{Criterion for Central East Region}

Central east region comprises of major monsoon stations and receives the highest amount of precipitation annually. To determine the onset in this region pentad rainfall methodology was adopted, according to which the date of monsoon onset over selected stations is the middle date of the 5-day period with the provision that the 5-day accumulated rainfall (with at least three rainy days) should not be less than $20 \mathrm{~mm}$ in this 31-day period (Faisal and Sadiq 2012).

\subsection{Criterion for Central West Region}

The monsoon precipitation penetrates to a greater extent in the central west region but far less than the central east region, hence a different criterion was adopted to determine the monsoon onset for this region. The criteria adopted by Faisal and Sadiq (2012) was modified and threshold for the criteria was changed to $10 \mathrm{~mm}$. Hence, in this region the middle date of the 5 -day period is considered as monsoon onset with the provision that the 5-day accumulated rainfall (with at least three rainy days) should not be less than $10 \mathrm{~mm}$ in this 31-day window.

\subsection{Criterion for North and South Region}

The monsoon system penetrates to a much lesser degree in the extreme north and south regions of Pakistan, so a general analysis of precipitation was made in these regions. The criteria of 7-day period was adopted for these regions with the provision of 7-day accumulated rainfall (with at least three rainy days) should not be less than $2 \mathrm{~mm}$.

\subsection{Statistical Analysis for Determination of Mean Onset}

The first step of statistical analysis includes determination of onset date of each year. For this purpose, the prescribed criteria were applied to each year from 1971 to 2010 and the onset date was calculated for every station included in this study. The next step was the determination of mean onset date of each of the four decades from 1971 to 2010 . For this, the formula of average was applied on the onset dates of four decades i.e. 1971-1980, 1981-1990, 1991-2000, and 20012010 , corresponding to each station of all four regions. To calculate onset dates for four regions, the average of the mean dates of all stations lying in the respective region was 
Table 2 Criteria used for determination of monsoon onset

\begin{tabular}{ll}
\hline Regions & Criteria for Monsoon Onset Determination \\
\hline Central East Region & $\begin{array}{c}\text { Middle date of the 5-day rainfall accumulated period (with at least three rainy days) in which rainfall should } \\
\text { not be less than } 20 \mathrm{~mm} .\end{array}$ \\
Middle date of the 5 -day rainfall accumulated period (with at least three rainy days) in which rainfall should \\
not be less than $10 \mathrm{~mm}$.
\end{tabular}

determined. In this way, a single average onset date for each region corresponding to every decade was determined. The standard deviation with respect to time period of onset was also calculated for each decade. To visualize the results, onset dates of four regions for each decade was plotted on the graph as well as on the map. In this way, four graphs corresponding to four stations were prepared to analyse the temporal variation in the onset of monsoon at various stations in Pakistan.

\subsection{Spatial Analysis of Monsoon Precipitation}

For analysing the spatial trends of average precipitation this study used IDW interpolation method. IDW interpolation method assumes that the things which are closer to each other have more features in common than those that are far from each other. To estimate a value for any unmeasured location, IDW uses the measured values surrounding the prediction location. The measured values closest to the prediction location have more influence on the predicted value than those farther away (ESRI 2017). While doing the interpolation the power was set as ' 2 '. The adjusted power 2 shows that the sample point values will provide better averaged output because sample points with unknown values that are far away from the location become more influential until all of the sample points have the same influence. Moreover, the search radius for nearest neighbour sample point was set as $5.327 \mathrm{~m}$. The resultant raster had a format of grid with cell size of 0.05 .

\section{Results}

The lifeline of Pakistan's water resources and agriculture is the summer monsoon rainfall which is received from the months of June to September. Any variability in the summer monsoon system can have major impacts on the irrigation as well as on the water resource management in the country. Uncertainty and uneven temporal and spatial distribution of rainfall may cause extreme situations such as flooding and long dry spells (Lai et al. 1998). This study provides an insight to the onset of summer monsoon season on the selected stations in Pakistan. Results of this study also indicate the spatial and temporal variability in the monsoon onset and precipitation in Pakistan.

\subsection{Analysis of Average Annual and Monsoon Precipitation of Study Area 1971-2010}

\subsubsection{Average Annual Precipitation 1971-2010}

Average annual precipitation in Pakistan ranges from $90 \mathrm{~mm}$ to $1750 \mathrm{~mm}$. The stations receiving maximum amount of precipitation annually lies in the Region II (central east) while those receiving the minimum precipitation lies in the Region IV (south region) of the country. The Fig. 2 shows that the Murree station received the maximum precipitation at the rate of $1727 \mathrm{~mm}$ annually from 1971 to 2010. The Balakot and Muzaffarabad stations received $1553 \mathrm{~mm}$ and $1500 \mathrm{~mm}$ of annual precipitation respectively and Dalbadin received the least annual precipitation i.e., $93 \mathrm{~mm}$ from 1971 to 2010. Also, the stations of Jacobabad and Khanpur received the least amount of annual precipitation from 1971 to 2010 i.e., $114 \mathrm{~mm}$ and $109 \mathrm{~mm}$ respectively.

\subsubsection{Average Monsoon Precipitation 1971-2010}

The analysis of monsoon precipitation shows that the Region II (central east) receive the maximum amount of rainfall during summer monsoon season (June-Sep). It shows that this region is the main part of the country receiving monsoon precipitation (Fig. 3). Some stations in the Region III (central west) also show receiving enough amount of precipitation during June-Sep. The results show minimal amount of precipitation received in Region I and Region IV in monsoon season from 1971 to 2010. The station showing maximum amount of average monsoon rainfall is Murree which received $914 \mathrm{~mm}$ precipitation from 1971 to 2010. The Balakot and Islamabad stations lies on the second and third rank with respect to monsoon precipitation receiving $855 \mathrm{~mm}$ and $791 \mathrm{~mm}$ respectively. The stations receiving minimum monsoon precipitation are Dalbadin, Quetta and Skardu which received $10 \mathrm{~mm}, 26 \mathrm{~mm}$ and $44 \mathrm{~mm}$ average monsoon precipitation respectively from 1971 to 2010 . 
Fig. 2 Annual precipitation in study regions for 1971-2010

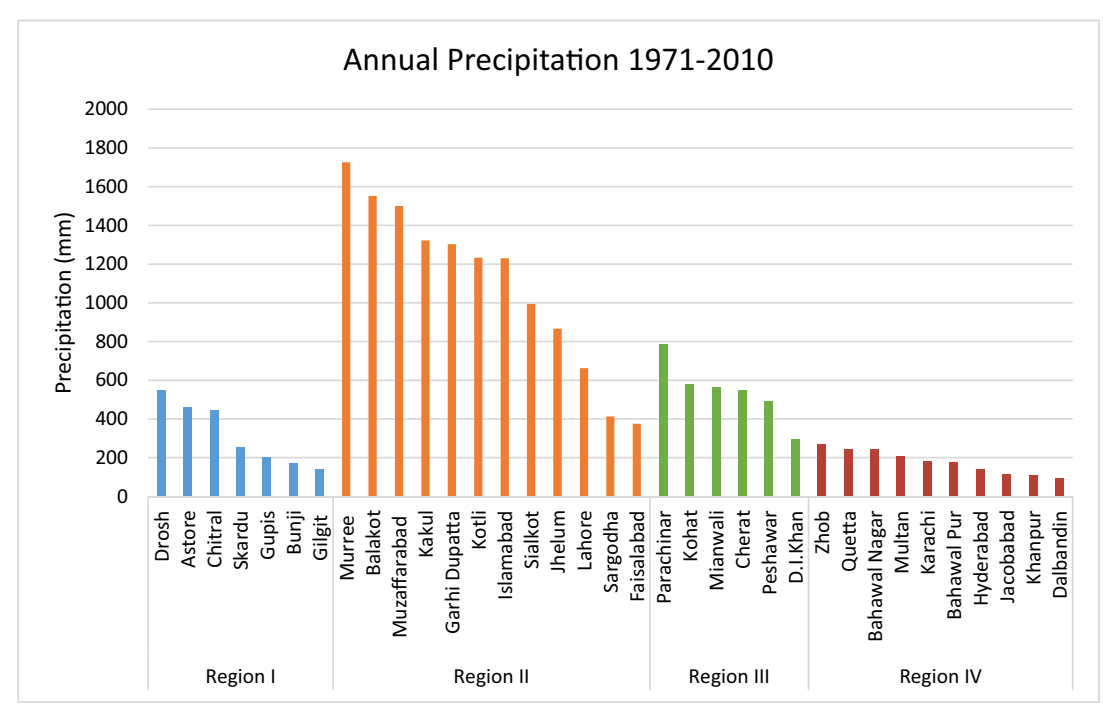

\subsection{Total Annual and Total Monsoon Precipitation of all Regions 1971-2010}

Results show that the Region II (central east) received highest total annual and total monsoon precipitation from 1971 to 2010. As shown in Fig. 4, the Region II received $\sim 12,000 \mathrm{~mm}$ total annual precipitation out of which the total monsoon precipitation received is $\sim 7500 \mathrm{~mm}$. The Region III (central west) received $\sim 3000 \mathrm{~mm}$ total annual precipitation out of which the total monsoon precipitation received is $\sim 1500 \mathrm{~mm}$ in the region. The total annual precipitation received in the Region I (north) is $\sim 2200 \mathrm{~mm}$ out of which the total monsoon precipitation is $\sim 500 \mathrm{~mm}$. In Region IV (south) the total annual precipitation received is $\sim 1700 \mathrm{~mm}$ and major portion of this precipitation is received in the monsoon season which is brought by the winds from the Arabian Sea. The total monsoon precipitation in this region is $\sim 1000 \mathrm{~mm}$.

\subsection{Evaluation of the Results of Homogeneity Test}

The results of the homogeneity test and the classification of stations is shown in Table 3. The Pettit's test results have shown that the Murree has homogeneous observations. There is no break point in this station's data. However, the homogeneity test graph shows occurrence of changes since 2001 i.e., the precipitation in determined period i.e., 20th June to 20th July is decreasing (Fig. 5 (a-f)). The mean value of precipitation is $273.85 \mathrm{~mm}$ in case of Murree. Similarly, the stations of Faisalabad, Sargodha and Sialkot have also a higher $p$ value thus their observation is homogeneous. The mean value is given as $85.5 \mathrm{~mm}, 72.42 \mathrm{~mm}$ and $229.18 \mathrm{~mm}$ respectively. In case of Jhelum and Lahore the null hypothesis is accepted (Table 3 ) thus observations are homogeneous. The mean value of precipitation is $176.08 \mathrm{~mm}$ for Jhelum and $140 \mathrm{~mm}$ for Lahore. The positive peaks are shown in the years 1975, 1979 and 1989 in case of Jhelum and in 1981 for Lahore (Fig. 5 (a-f)). The stations of Muzafarabad and Kakul
Fig. 3 Monsoon precipitation in study regions for 1971-2010

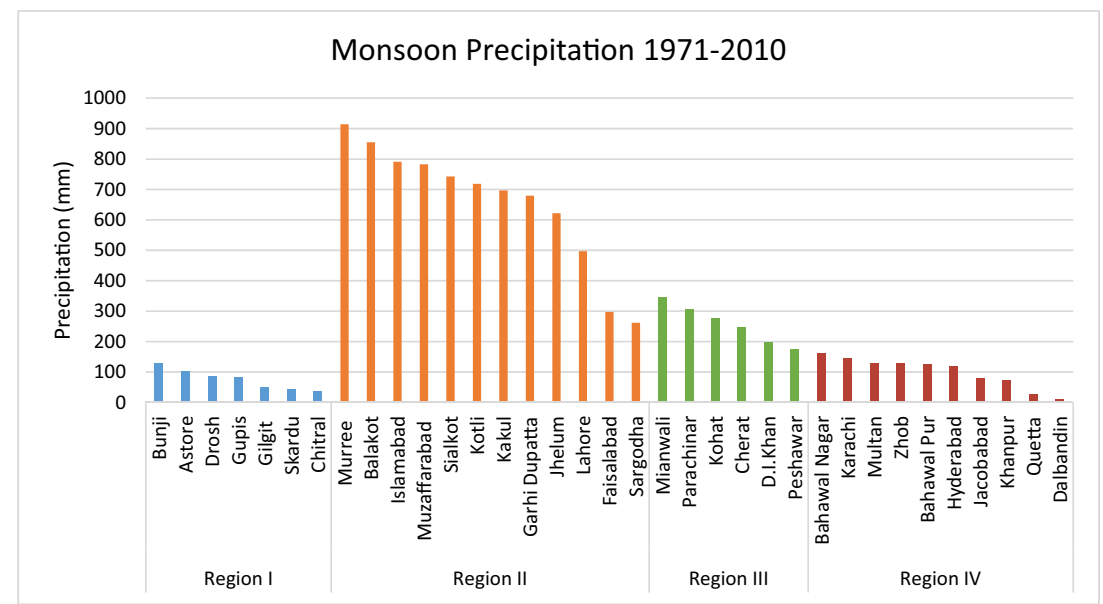


Fig. 4 Total annual and total monsoon precipitation of four studied regions
Total Annual and Total Monsoon Precipitaion (1971-2010)

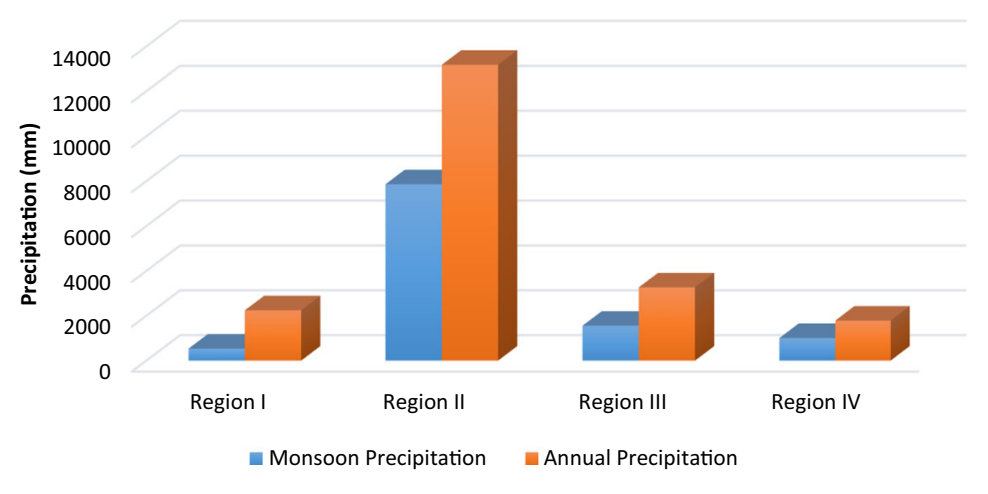

have also homogenous observations. The mean precipitation is $\sim 266 \mathrm{~mm}$ and $\sim 196.42 \mathrm{~mm}$ respectively. In the year 1978 the highest positive peaks were observed in Muzafarabad and Kakul. Similarly, for Grahidupatta and Kotli, the observations are homogeneous. The mean values of precipitation and peaks are shown in Fig. 5 (g-1). The stations of Mianwali, Dera Ismail Khan and Parachinar have homogeneous observations. The mean value for precipitation is $91.95,49.8$ and $72 \mathrm{~mm}$ respectively. The peaks have been observed in the years 1980 and 2008 for Mianwali, in the year 2000 for Dera Ismail Khan and in the year 1983 for Parachinar. A slight change has been observed in Mianwali in year 1979, after which frequent peaks have been observed (Fig. $5(\mathrm{k}-\mathrm{m})$ ). Similarly, Kohat and Peshawar the observations are homogeneous. Their respective mean values and peaks are shown in Fig. 5 ((n-o)). The stations of Skardu, Gilgit and Astore with mean value of precipitation $9.8 \mathrm{~mm}, 11.5 \mathrm{~mm}$ and $33.3 \mathrm{~mm}$ respectively, have also homogeniety. In Skardu and Gilgit highest positive peak is observed in the year 1996 while for Astore it is observed in 1985. Like previous stations, Bunji, Chitral and Drosh have also shown homogeneity. The mean precipitation and peak values are shown in Fig. 5 (p-t). Similarly, Bahawalpur, Multan and Bahawalnagar have homogeneous observations. The mean of precipitation is $66 \mathrm{~mm}$ for Bahawalnagar, $72.12 \mathrm{~mm}$ for Multan and $\sim 30 \mathrm{~mm}$ for Bahawalpur. The highest peak is observed in the year 1978 for Bhawalpur and Bahawalnagar and in the year 1993 for Multan (Fig. 5 (u-ac)). The stations of Hyderabad, Khanpur and Jacobabad have homogeneous observations (Table 3 ). The mean value of precipitation for these stations is $25 \mathrm{~mm}, 12.6 \mathrm{~mm}$ and $23 \mathrm{~mm}$ respectively. The highest peak in Jacobabad is observed in year 1978, for Hyderabad in year 1976 and for Khanpur in 1993. Similarly, the stations Zhob and Dalbadin have homogeneous observations, the mean value of precipitation is $47 \mathrm{~mm}$ for Zhob and $6 \mathrm{~mm}$ for Dalbadin (Fig. 5 (v-ac)). The results of homogeneity tests showed that maximum number of stations have consistent observations. All these above-mentioned stations are classified as "Class A". It means that the observations are homogenous and no clear sign of an in-homogeneity in the precipitation data is present.

Four stations observed abrupt shifts i.e., Gupis, Cheerat, Balakot and Islamabad. Abrupt shifts have been observed in Gupis in year 1991, in year 1980 in Cheerat and in year 1981 in Balakot. Similarly, the station of Islamabad has shown a shift in year 2008. Presence of these break points and $p$ value (Table 4) depicts chances of in-homogeneity in the rainfall data at these stations. These break points are the detected change points in the time series. Thus, all these four stations are classified as "Class B". Due to breaks two mean values are computed as shown in Table 4. In case of Islamabad, Balakot and Cheerat there is abrupt change of precipitation toward lower values while in case of Gupis this abrupt change is showing an increase in precipitation in the defined period of 31 days (Fig. 5 (ad-ag)).

\subsection{Spatial Variability Analysis of Monsoon Precipitation}

The IDW interpolation of daily average and monthly average precipitation from 20th June - 20th July has been shown for the period of 1971-2010. The area receiving higher rainfall in the specified period i.e., 20th June - 20th July has decreased over time as shown in Fig. 6 (a-d). Most of the precipitation accumulated in central eastern region while other regions received less precipitation. In case of summer precipitation that occurs due to winds from the Arabian Sea in extreme south of Pakistan, the area receiving precipitation is quite small which has decreased over the course of four decades, hence the aridity of the southern region has increased over the period of 1971-2010. The interpolated results for 1971-1980 have shown more precipitation all over the country as compared to the results of other three decades. 
Table 3 Results of homogeneity test

\begin{tabular}{|c|c|c|c|c|c|}
\hline Station & $\begin{array}{l}P \text { Value } \\
(<\text { a or }>\text { a })\end{array}$ & $\begin{array}{l}\text { Break } \\
\text { point }\end{array}$ & $\begin{array}{l}\mathrm{H}_{0} \text { accepted or } \\
\text { rejected }\end{array}$ & Classification & $\begin{array}{l}\text { Homogeneous } \\
\text { (Yes or No) }\end{array}$ \\
\hline Dalbadin & $0.956>0.05$ & & Accepted & A & Yes \\
\hline Zhob & $0.131>0.05$ & & Accepted & A & Yes \\
\hline Quetta & $0.605>0.05$ & & Accepted & $\mathrm{A}$ & Yes \\
\hline Karachi & $0.621>0.05$ & & Accepted & A & Yes \\
\hline Jacobabad & $0.748>0.05$ & & Accepted & $\mathrm{A}$ & Yes \\
\hline Hyderabad & $0.976>0.05$ & & Accepted & $\mathrm{A}$ & Yes \\
\hline Gupis & $0.009<0.05$ & 1991 & Rejected & $\mathrm{B}$ & No \\
\hline Astore & $0.288>0.05$ & & Accepted & A & Yes \\
\hline Gilgit & $0.208>0.05$ & & Accepted & A & Yes \\
\hline Bunji & $0.800>0.05$ & & Accepted & A & Yes \\
\hline Skardu & $0.769>0.05$ & & Accepted & A & Yes \\
\hline Muzafarabad & $0.532>0.05$ & & Accepted & A & Yes \\
\hline Kotli & $0.098>0.05$ & & Accepted & A & Yes \\
\hline Garhidupatta & $0.486>0.05$ & & Accepted & A & Yes \\
\hline Peshawar & $0.271>0.05$ & & Accepted & A & Yes \\
\hline Kohat & $0.367>0.05$ & & Accepted & A & Yes \\
\hline Parachinar & $0.657>0.05$ & & Accepted & A & Yes \\
\hline Kakul & $0.585>0.05$ & & Accepted & $\mathrm{A}$ & Yes \\
\hline Drosh & $0.825>0.05$ & & Accepted & A & Yes \\
\hline D.I. Khan & $0.247>0.05$ & & Accepted & A & Yes \\
\hline Chitral & $0.434>0.05$ & & Accepted & A & Yes \\
\hline Cheerat & $0.038<0.05$ & 1980 & Rejected & $\mathrm{B}$ & No \\
\hline Balakot & $0.036<0.05$ & 1981 & Rejected & $\mathrm{B}$ & No \\
\hline Sargodha & $0.204>0.05$ & & Accepted & $\mathrm{A}$ & Yes \\
\hline Sialkot & $0.314>0.05$ & & Accepted & $\mathrm{A}$ & Yes \\
\hline Multan & $0.874>0.05$ & & Accepted & $\mathrm{A}$ & Yes \\
\hline Lahore & $0.542>0.05$ & & Accepted & A & Yes \\
\hline Khanpur & $0.519>0.05$ & & Accepted & A & Yes \\
\hline Mianwali & $0.341>0.05$ & & Accepted & A & Yes \\
\hline Jehlum & $0.570>0.05$ & & Accepted & A & Yes \\
\hline Faisalabad & $0.867>0.05$ & & Accepted & A & Yes \\
\hline Bahawalpur & $0.733>0.05$ & & Accepted & A & Yes \\
\hline Bahawalnagar & $0.997>0.05$ & & Accepted & A & Yes \\
\hline Murree & $0.740>0.05$ & & Accepted & A & Yes \\
\hline Islamabad & $0.047<0.05$ & 2008 & Rejected & B & No \\
\hline
\end{tabular}

\subsection{Temporal Variability Analysis of Monsoon Onset}

The analysis to determine the variability in onset of monsoon was carried out for four objectively defined regions as well as for individual stations. The results show the variability of regional onset of summer monsoon season over the period of four decades i.e., 1971-2010 and are presented as follows:

\subsubsection{Monsoon Onset over Region I}

The Region I (north) comprise of seven stations and an overall monsoon trend in this region depicts that the monsoon onset has shifted to an earlier time (Fig. 7). In the decade of 1971-80, monsoon onset was in the start of July i.e., 2nd July \pm 7 days which was shifted to 8 th July \pm 6 days in the next decade i.e., 1981-1990. However, in 1991-2000-decade, monsoon onset shows a significant shift towards the end of June i.e., 30th June \pm 6 days and this trend continued in the next decade i.e., 2001-2010, in which the monsoon onset was on 27 th June \pm 6 days. There is a sharp shift in onset trend from the first week of July to last week of June in the Region I during the studied period. 


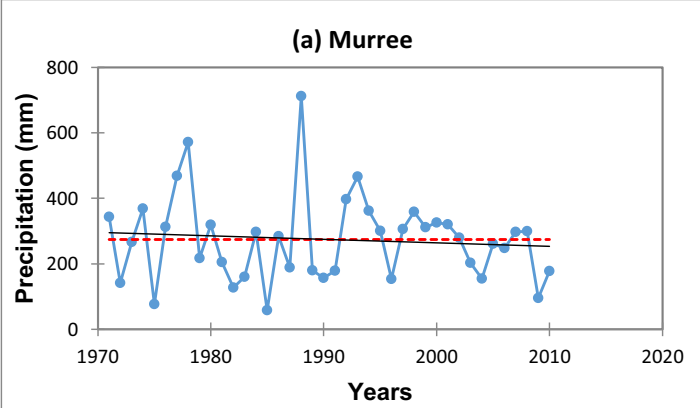

$\longrightarrow$ Murree -.----- mu = $273.875 \longrightarrow$ Linear (Murree)

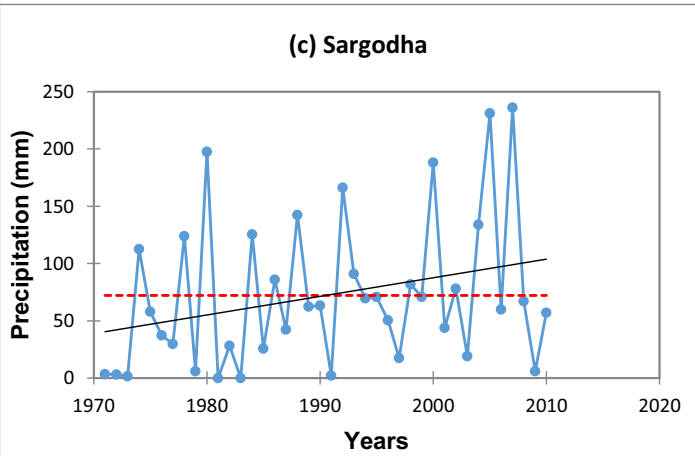

$\longrightarrow$ Sargodha $-\cdots---$ mu $=72.245 —$ Linear (Sargodha)

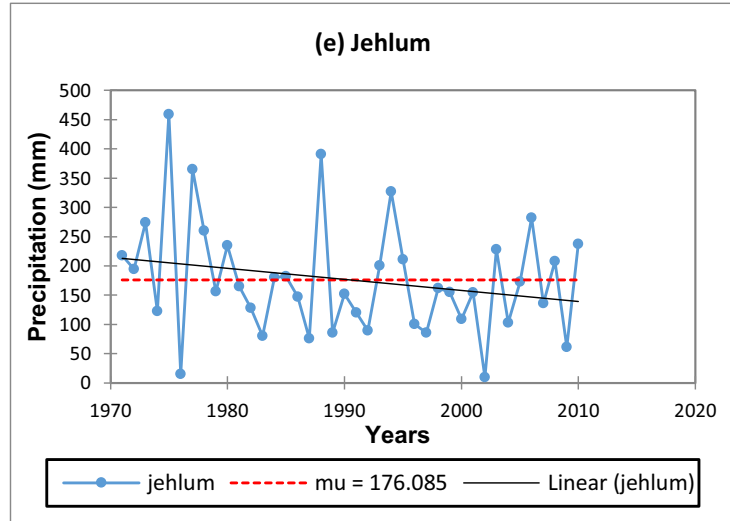

(b) Faisalabad

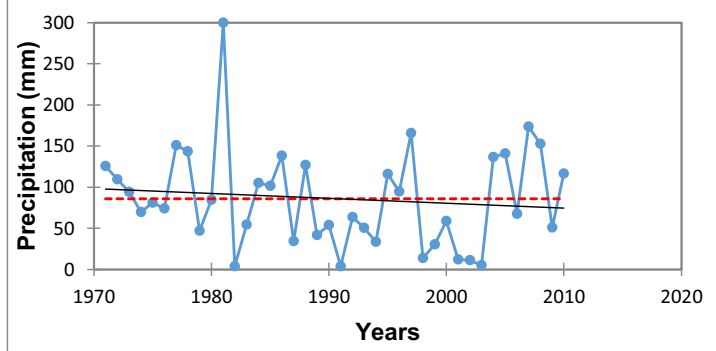

$\longrightarrow$ faisalabad $-\ldots-\ldots$ mu $=85.919 \longleftarrow$ Linear (faisalabad)

(d) Sialkot

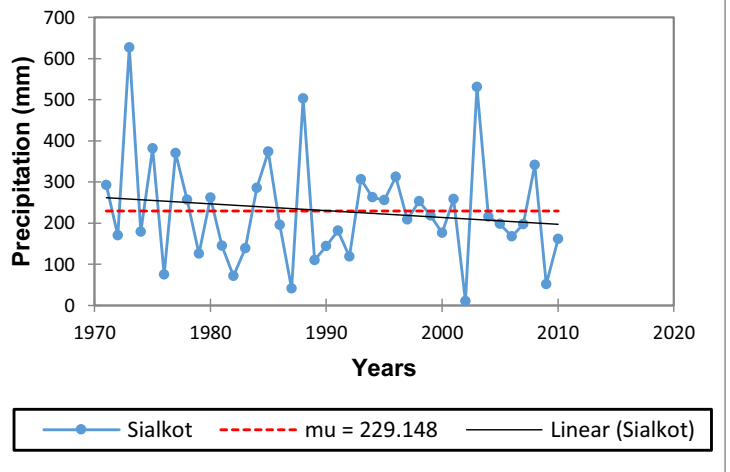

(f) Lahore

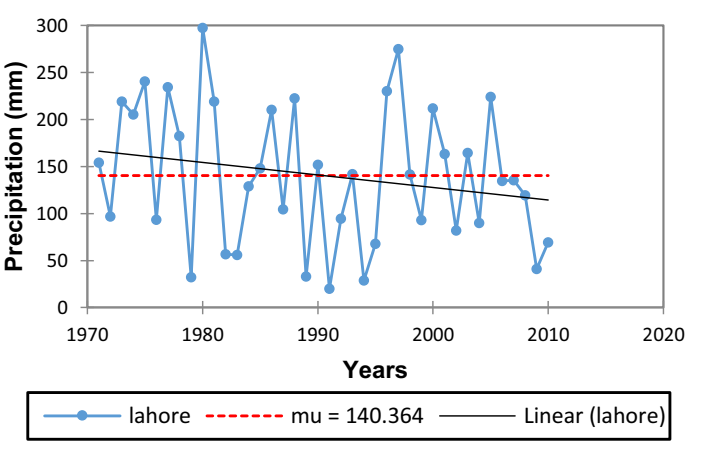

Fig. 5 a-ag Homogeneity test analysis for stations in different region in Pakistan showing the trend of precipitation over the period of 1971-2010

\subsubsection{Monsoon Onset over Region II}

The Region II (central east) receives rainfall during summer monsoon season from the currents transported from the Bay of Bengal that are later deflected by Himalayas and fall as precipitation in northeast of Pakistan. While investigating the variation in onset time of monsoon it is evident that the central eastern region has shown an overall earlier onset of summer monsoon over the course of four decades i.e., 1971-2010. It is also shown from the analysis that three decades i.e.,
1971-1980, 1991-2000 \& 2001-2010 had earlier onset of monsoon while the decade (1981-1990) showed late onset of monsoon season. The mean onset calculated for Region II for the decade 1971-1980 is 1st July with standard deviation of 6 days, which is quite high. The onset for the decade 1981-1990 is determined to be 3rd July while the standard deviation of 3 days. In 19912000 , the onset in this region shifted to 29th June with a standard deviation of 4 days. Similarly, the onset for 2001-2010 decade is 29th June with a standard deviation of 3 days (Fig. 8). 

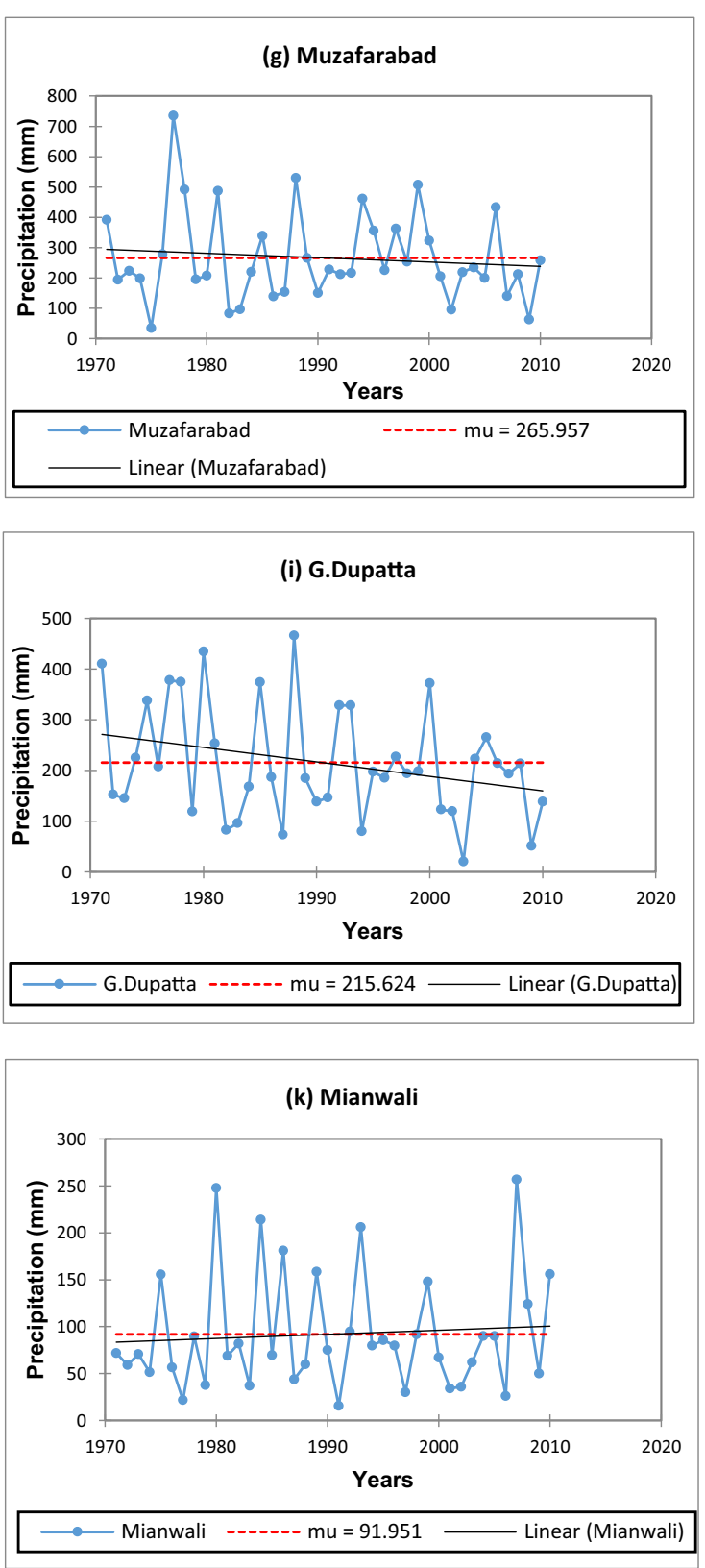

Fig. 5 (continued)

\subsubsection{Monsoon Onset over Region III}

The Region III (central west) comprise of stations where monsoon reaches after the Region II. The amount of precipitation received in this region is less as compared to the CMRP. The analysis of variation in monsoon onset of Region III shows that the trend in the monsoon onset is consistent with the central east region (Fig. 9). In the decade of 1971-1980, the onset occurred at the mean date of 6th July with the standard deviation of 4 days after which an earlier mean onset was observed in the next decade on 5th July \pm 2 days in 1981-1990.
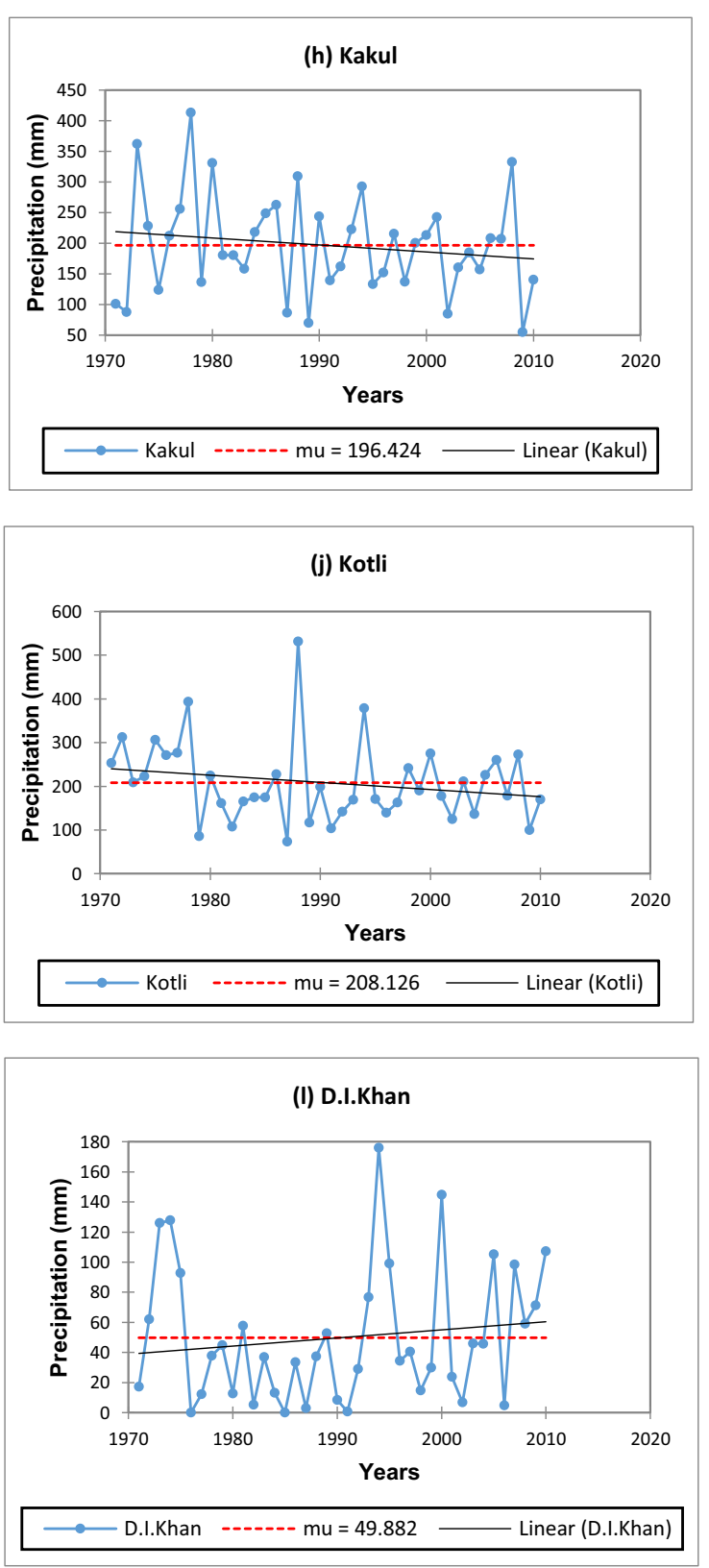

In the decade of 1991-2000, the mean onset remained constant at 5th July with standard deviation of 3 days, however the mean onset again shifted toward earlier July i.e., 3rd July \pm 3 days in 2001-2010. Hence, the central west region shows an overall shift towards earlier onset in the summer monsoon during 1971-2010.

\subsubsection{Monsoon Onset over Region IV}

The Region IV (south) of the country consists of stations which receives their share of rainfall from the Arabian Sea during summer monsoon season. This 

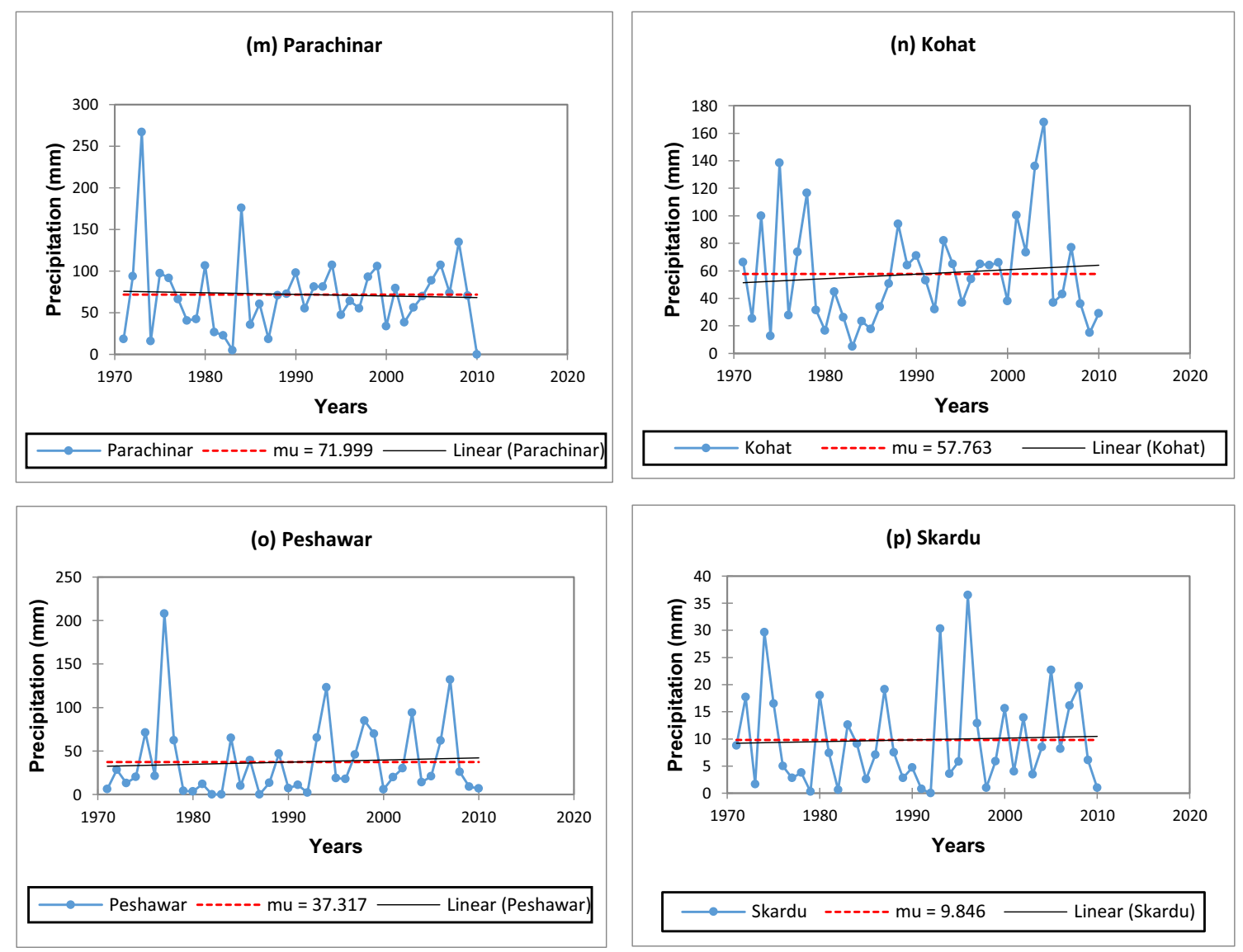

Fig. 5 (continued)

region receives rainfall far less than the north eastern part of the country (i.e., Region II) (Imran et al. 2014). The temporal analysis of the monsoon onset in Region II shows a consistent shift toward earlier onset over the period of four decades i.e., 1971-2010. In 1971-80, the mean onset date was observed to be 5th July with the standard deviation of 1 day while the mean onset shows backward shift in the next three decades i.e., 4th July, 3rd July and 2nd July in 1981-90, 1991-2000 and 2001-2010 respectively. Hence, it can be concluded based on analysis that the onset in Region III is showing a shift towards start of July (Fig. 10). Overall monsoon onset and standard deviation in all studied regions has been shown in Fig. 11.

\subsection{Individual Station Analysis for Variability of Monsoon Onset}

\subsubsection{Individual Station Analysis of Region I (North)}

In Astore, the monsoon onset has a shift from the first week of July to the last week of June. Similarly, in Bunji, monsoon onset has shifted from the first week of July to the last week of June. In Gupis the monsoon onset does not show any significant shift but there is variability in onset within the last week of June. In Chitral there is a shift in monsoon onset from the first week of July to the last week of June. In Drosh there is a significant shift in the monsoon onset i.e., from the first week of July to the third week of June. In Gilgit the monsoon onset mostly remained steady in the first week of July. The trend line shows the variability within the days of first week of July for Gupis. However, a significant shift can be seen in Skardu which explains that the monsoon onset has shifted to earlier time. The shift has occurred from the first week of July to the last week of June (Fig. 12 (a-g)).

\subsubsection{Individual Station Analysis of Region II (Central East)}

In Murree, a significant shift in monsoon onset has been observed from end of June to the third week of June during the studied period. In Islamabad, the monsoon onset shows a significant shift from first week of July towards last week of June from 1971 to 2010. The Kotli has shown a significant shift in monsoon onset 

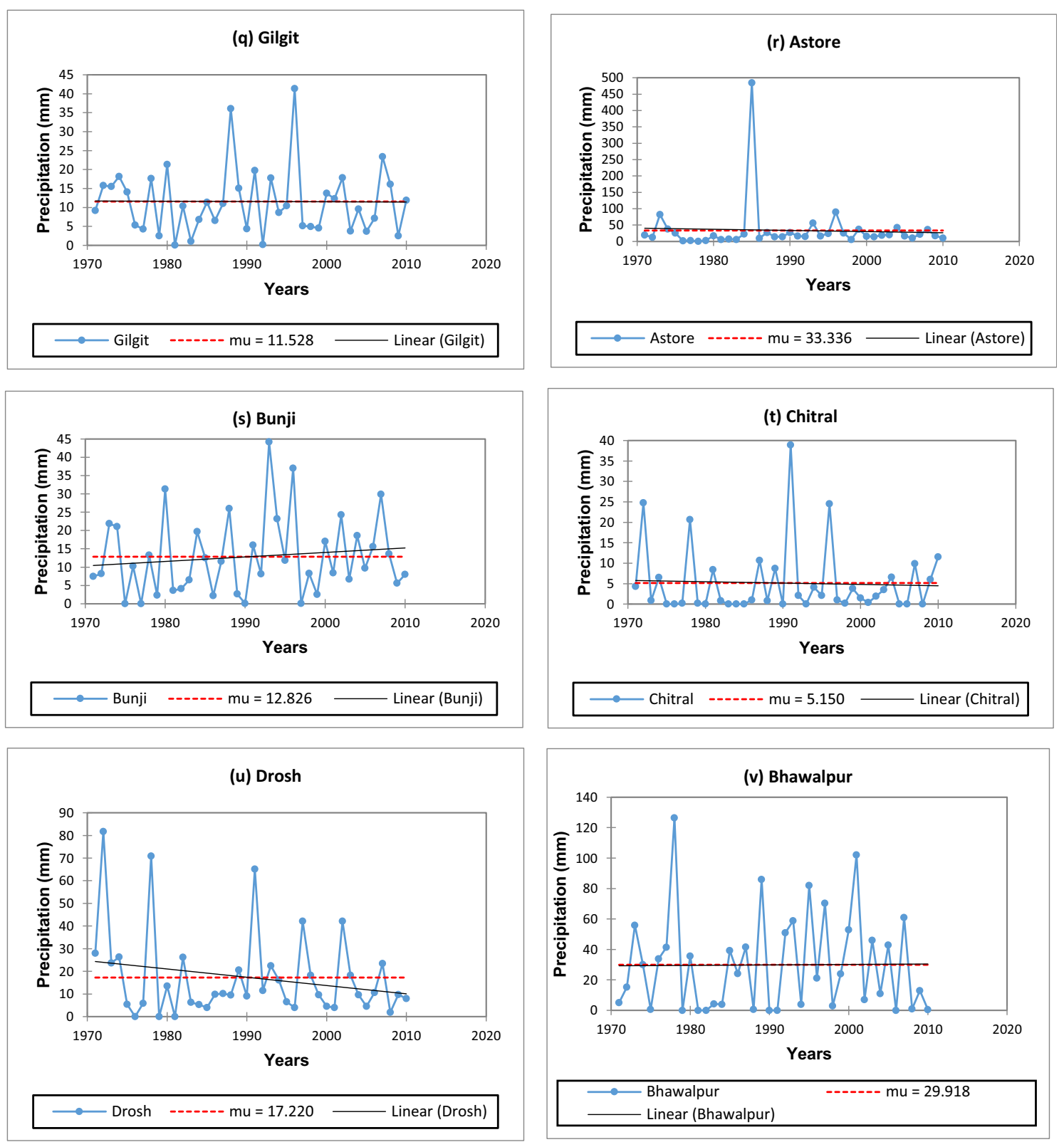

Fig. 5 (continued)

from early July (in 1980's) to the end of June in 200110 period. In Faisalabad, a significant shift in monsoon onset can be seen from second week of July to first week of July. The Sargodha has shown a significant shift in monsoon onset from end of second week of July to early July. The station of Balakot has steady onset of monsoon. In case of Balakot, the onset time remained in June but kept on moving over course of four decades. The monsoon onset at Balakot station was in the third week of June during 1970's decade which then moved upward to the end of June during the next two decades (1980's \& 1990's) and later shifted to 23rd of June (Fig. 13(a-f)).
The onset of monsoon in Muzafarabad has a steady trend like Balakot. The Garhi Dupatta has a significant shift of monsoon onset from early July during 1980's to 25th of June during 2001-10 period. The Kakul has a significant shift of monsoon onset from first week of July to last week of June. In Lahore the monsoon onset is in the first week of July and remained steady throughout the study period. In Jhelum the monsoon onset remained steady during the first three decades i.e., 1971-2000 however shifted from early July to the end of June in the last decade i.e., 2001-2010. The monsoon onset in Sialkot has shifted from 1st July in 1970's decade to 25th of June in 2000's decade (Fig. 13 

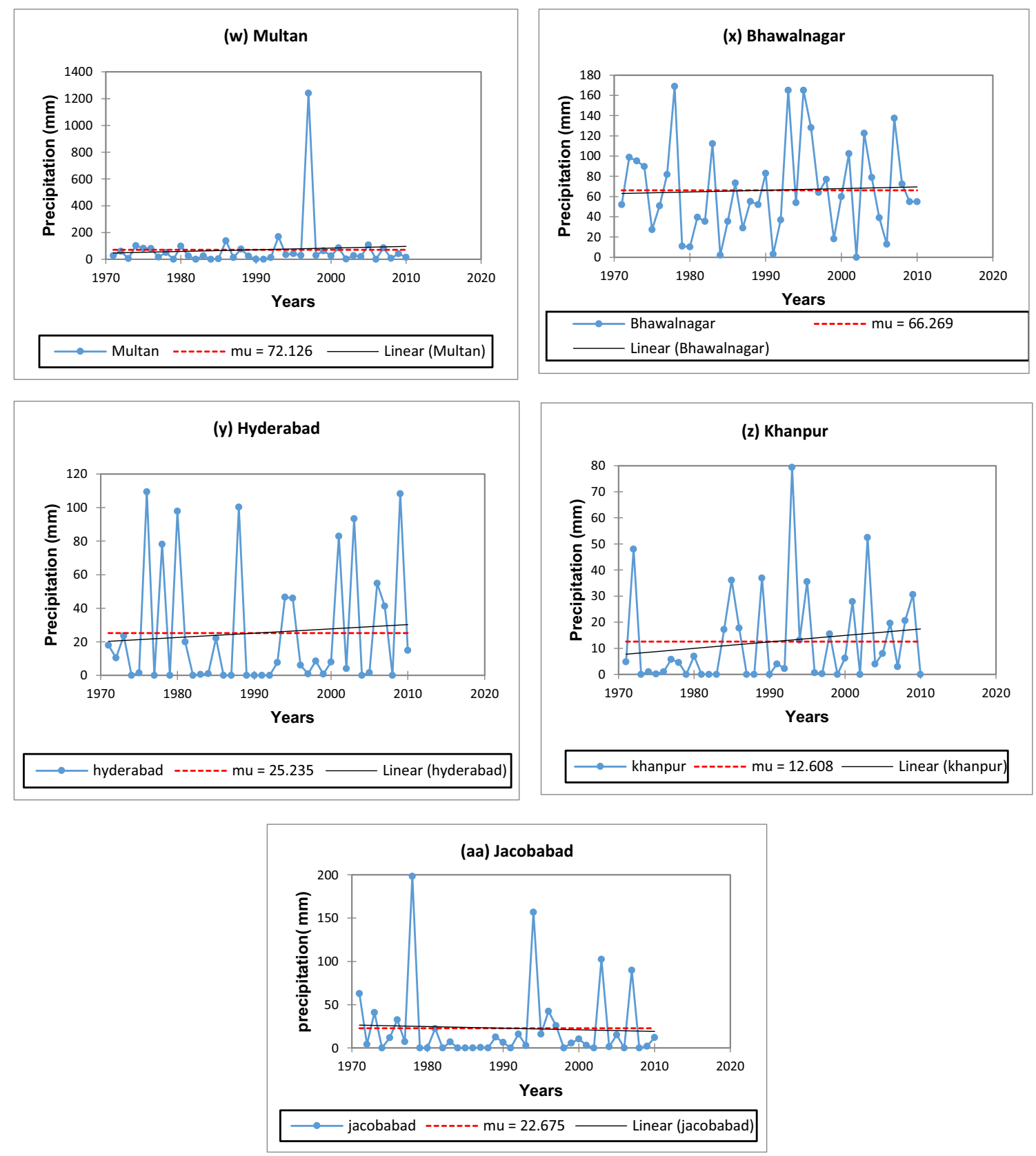

Fig. 5 (continued)

(g-1)). In almost all of the stations the onset of monsoon in 1980's appeared to occur in the first or second week of July. While in remaining three decades the onset remained in June with some exceptions like Faisalabad, Sargodha and Lahore etc.

\subsubsection{Individual Stations Analysis of Region III (Central West)}

In Mianwali, the monsoon onset shows a steady trend during the four decades (i.e., 1971-2010) as it has shifted from first week of July to the end of June. In Kohat, the onset shifted from second week of July to the first week of July. The
Parachinar station received the highest amount of precipitation as compared to other stations in this region (cf. Shah et al. 2012). The station shows onset of monsoon in the month of June as compared to other stations in the central west region where onset occurred mostly in the month of July. However, the trend of mean onset dates among four decades is similar to that of other stations where mean onset is shifting towards earlier time i.e. from first week of July to the third week of June. The mean onset trend in D.I.Khan is similar to that of Parachinar as the second decade i.e., 1981-1990 shows a shift towards late monsoon onset as compared to the first decade i.e., 1971-1980. However, the overall trend 

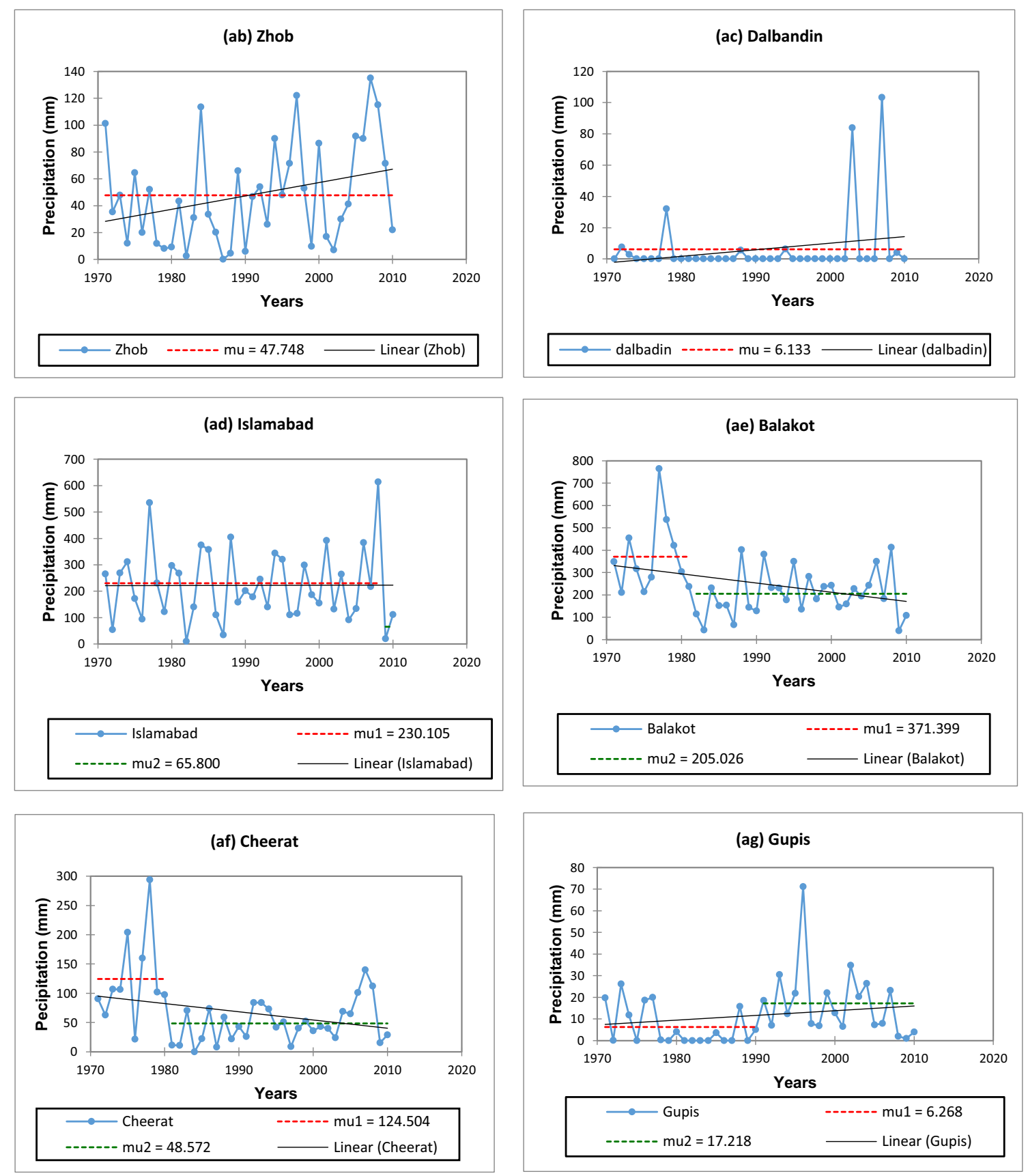

Fig. 5 (continued)

of monsoon onset is not as significant as on other stations in the region, but it shows a trend of earlier onset of monsoon with a shift to the start of July. In

Peshawar and Cherat a shift in monsoon onset has been observed from second week of July towards the first week of July (Fig. 14(a-f)).

Table 4 Table showing mean precipitation values before and after break point of stations with inhomogeneity

\begin{tabular}{lll}
\hline Station & $\mu 1$ (Mean value of precipitation before Break point) & $\mu 2$ (Mean value of precipitation after Break point) \\
\hline Islamabad & 230.1 & 65.8 \\
Balakot & 371.3 & 205.02 \\
Cheerat & 124.5 & 48.5 \\
Gupis & 6.26 & 17.2 \\
\hline
\end{tabular}




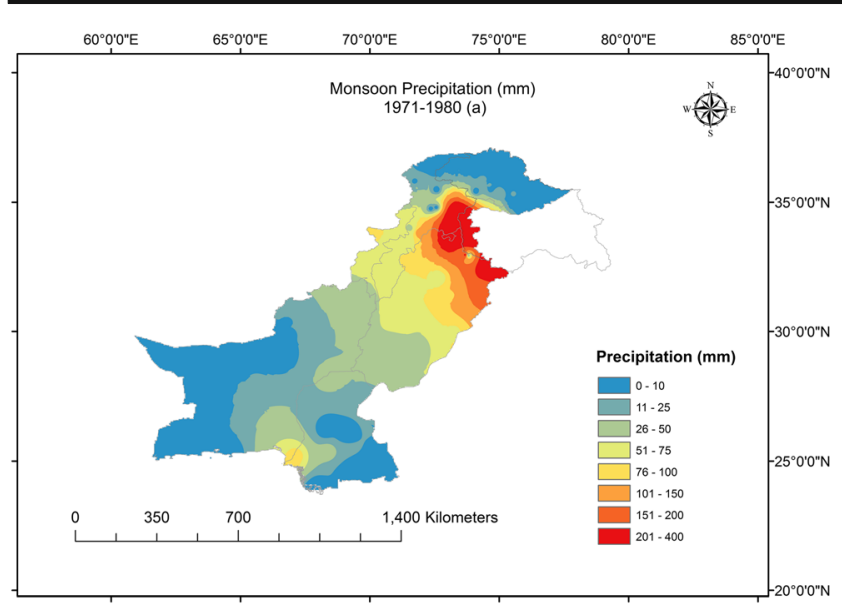

(a)

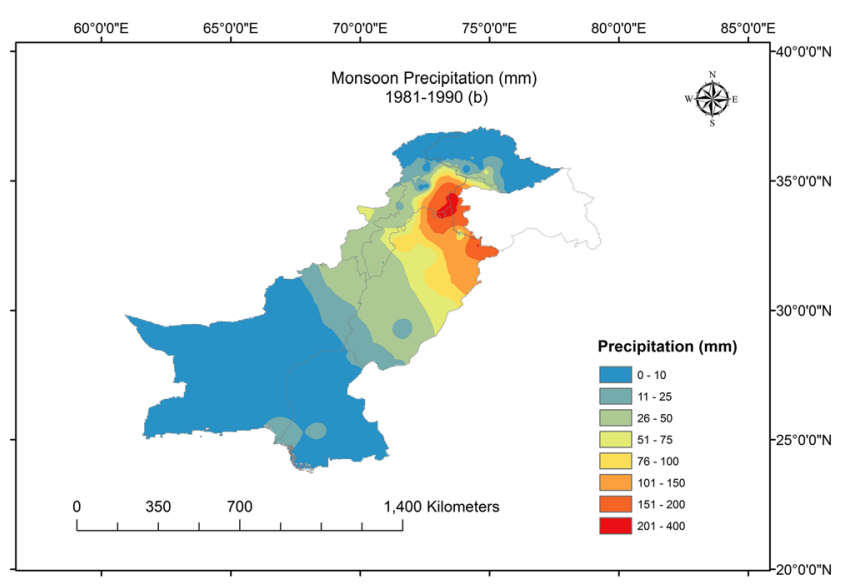

(b)

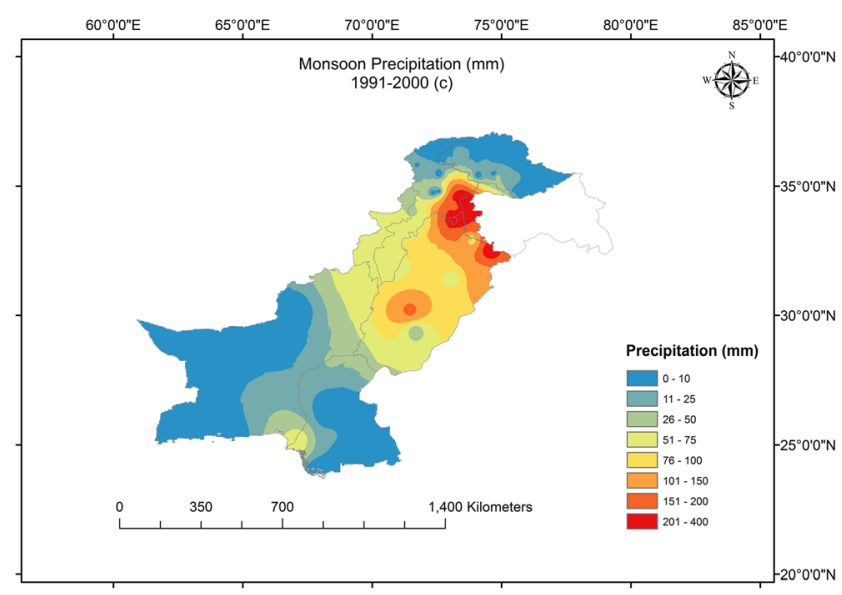

(c)

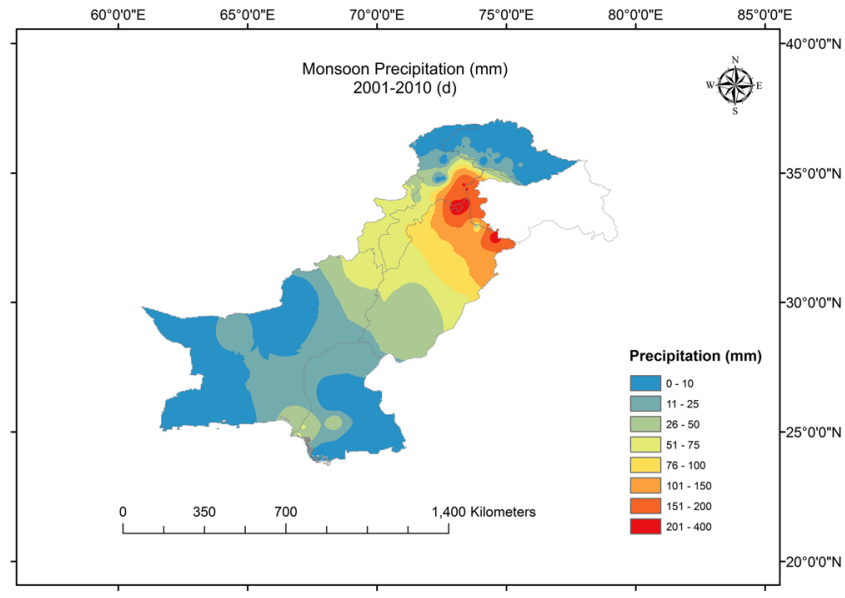

(d)

Fig. 6 Map of study region showing spatial variability of monsoon rainfall from 1971 to 2010 over Pakistan (a) 1971-1980 (b) 1981-1990 (c) 19912000 (d) 2001-2010

\subsubsection{Individual Station Analysis of Region IV (South)}

The monsoon onset in Multan station is consistent with the trend of other stations in Region IV. The station shows constant mean onset in the first three decades after which a shift towards earlier onset is observed in the fourth decade i.e., 2001-2010. In Jacobabad a significant shift in monsoon onset has been observed i.e., towards early July after the first decade (i.e., 19711980). The mean onset shows variations within the first
Fig. 7 Trend of monsoon onset over northern region (Region I) from 1971 to 2010

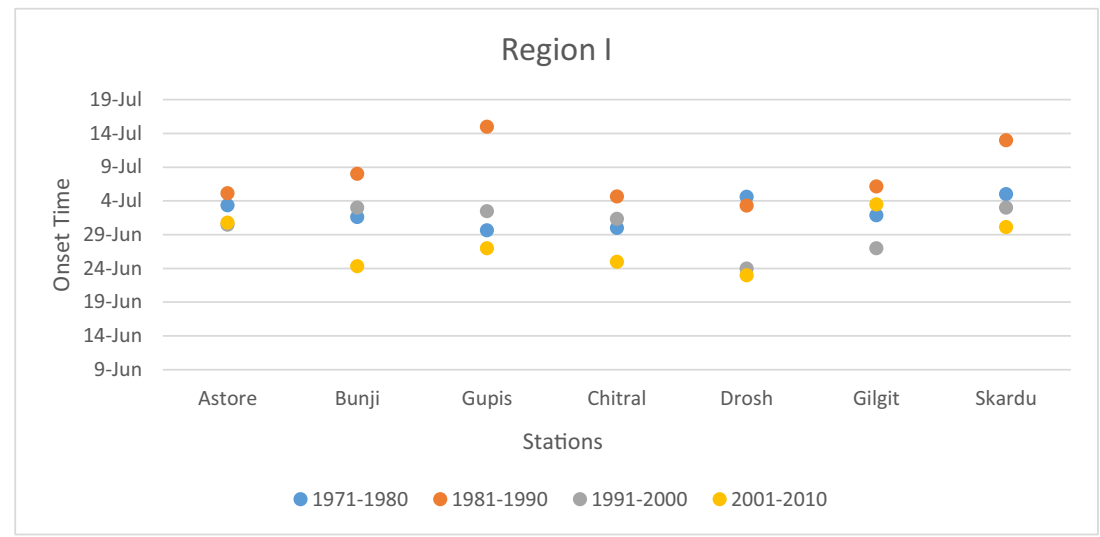


Fig. 8 Trend of monsoon onset over central east region (Region II) from 1971 to 2010

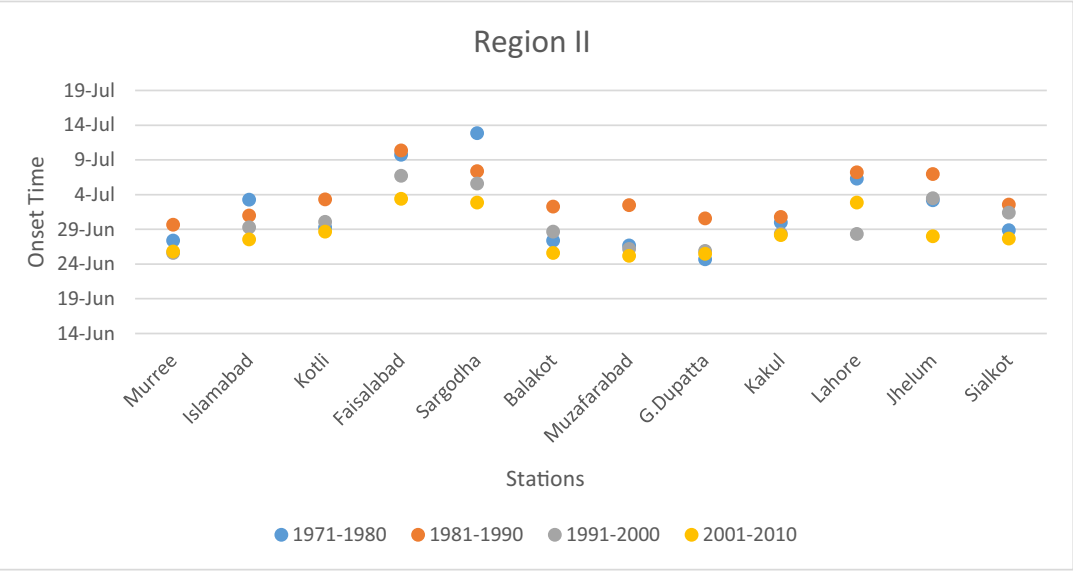

week of July over the period of four decades in Jacobabad. In Khanpur there is variability in the monsoon onset over the four decades. The onset shows a sharp forward shift in the second decade i.e., 19811990 as compared to the first decade (i.e., 19711980); it again comes to the same date in the third decade (i.e., 1991-2000) after which a shift to the earlier time in mean onset is observed in the last decade (i.e., 2001-2010), however the overall trend has not shifted significantly. The trend in monsoon onset over Bahawalpur is similar to that of Jacobabad in which the mean onset seems to be sharply shifted to the last week of June.

In Karachi, the monsoon onset in the first two decades (i.e., 1971-1980 \& 1981-1990) shows a shift to the earlier time however in the third decade (i.e., 19912000) the mean date shows forward shift after which it again followed the shift to earlier time in the fourth decade (i.e., 2001-2010). In Hyderabad, the trend does not show any significant shift and the monsoon onset remained during the first week of July throughout the study period. The trend in monsoon onset for the stations of Zhoab and Bahawalnagar show a steady shift to earlier time in monsoon onset. However, the monsoon onset for the last decade in Zhoab was observed at the end of June while all other stations show monsoon onset in early July (Fig. 15 (a-h)).

\subsubsection{Overall Monsoon Trends of Regions}

The average summer monsoon rainfall (June-JulyAugust) for the 40-year period 1970-2010 in the Regions (I, II and III) and Region IV of Pakistan are plotted with the standardized values in Figs. 16, 17, and 18. A recent study by Preethi et al. (2017) suggests a decreasing trend in summer monsoon rainfall over southern parts of Pakistan which comprises of our Region IV and increasing trend over the northern parts of Pakistan i.e., Region I, II and III in this study.

\section{Discussion}

The current study indicates inter-decadal spatial and temporal variability in the precipitation related to the monsoon onset in Pakistan. The results are consistent
Fig. 9 Trend of monsoon onset over central west region (Region III) from 1971 to 2010

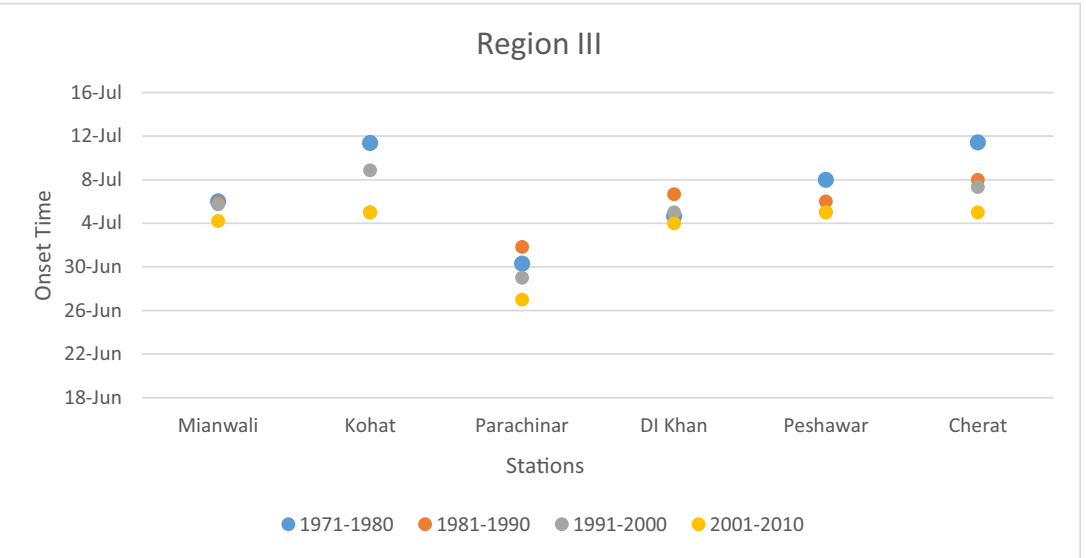


Fig. 10 Trend of monsoon onset over southern region (Region IV) from 1971 to 2010

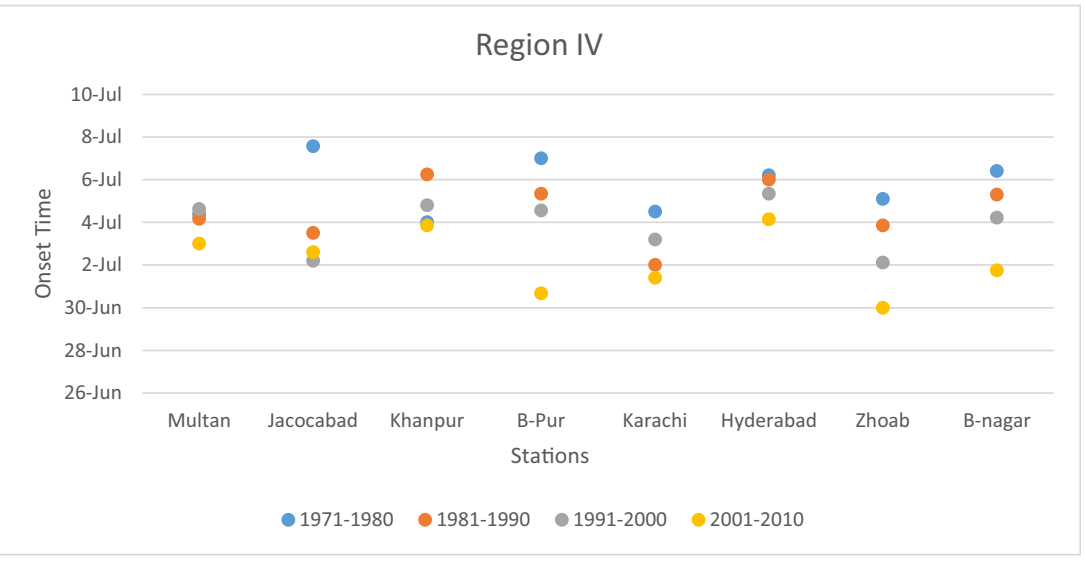

with the studies carried out around the globe indicating the changes in the summer monsoon rainfall in South Asia including Pakistan (Das et al. 2013; Imran et al. 2014; Latif and Syed 2015). Seasonal mean rainfall in south Asia shows interdecadal variability, particularly in terms of declining trend with frequently occurring deficiency in summer monsoon rainfall (Intergovernmental Panel on Climate Change 2014). In this regard, Pakistan has a noticeable share in the large climatic variations taken place in the northwest India during the Holocene which has caused the spatial shifts in the rainfall pattern of the region (Bryson and Murray 1977).

The analysis of temporal variability in monsoon shows that the mean onset has shifted from earlier July to the end of June. The results are consistent for all the four regions as well as for all the stations included in the study. This trend of earlier onset follows the study carried out by Imran et al. (2014), which include the major stations of the Region II constituting CMRP. This study also shows the time of monsoon onset at the stations like Islamabad and Lahore which agrees with the results of the current study. Moreover, the calculated onset time using the criteria agrees with the time calculated by Latif and Syed (2015). However, minor differences exist in the mean onset time shown in this study as compared to the previous studies on selected stations (c.f. Latif and Syed 2015). The studies of Imran et al. (2014) and Latif and Syed (2015) are limited to Region II and CMRP respectively while the current study cover almost whole of Pakistan and provides the depth analysis of variability in the monsoon onset. The assessment has been carried out for each station individually as well as for different regions of Pakistan which provide a comprehensive picture of previous monsoon onset trends in Pakistan. Moreover, this study provides a reliable base for conducting future projection studies relevant to monsoon trends in Pakistan. The shift in monsoon onset may be due to the changes in the specific humidity over the Indian Ocean and Arabian Sea (Sahana et al. 2015).

It is noted that, during the time period 1981-1990, the onset on all stations have shown a significant delay. This delay might be attributed to the unusual climatic
Fig. 11 Standard deviation of monsoon onset in four regions of Pakistan over the four decades from 1971 to 2010

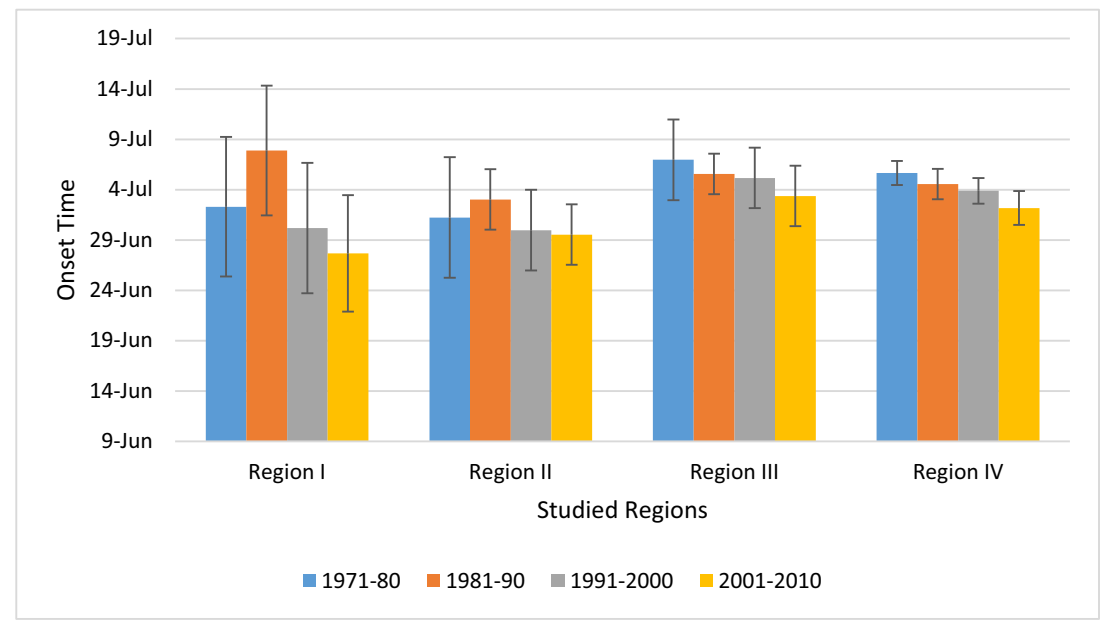




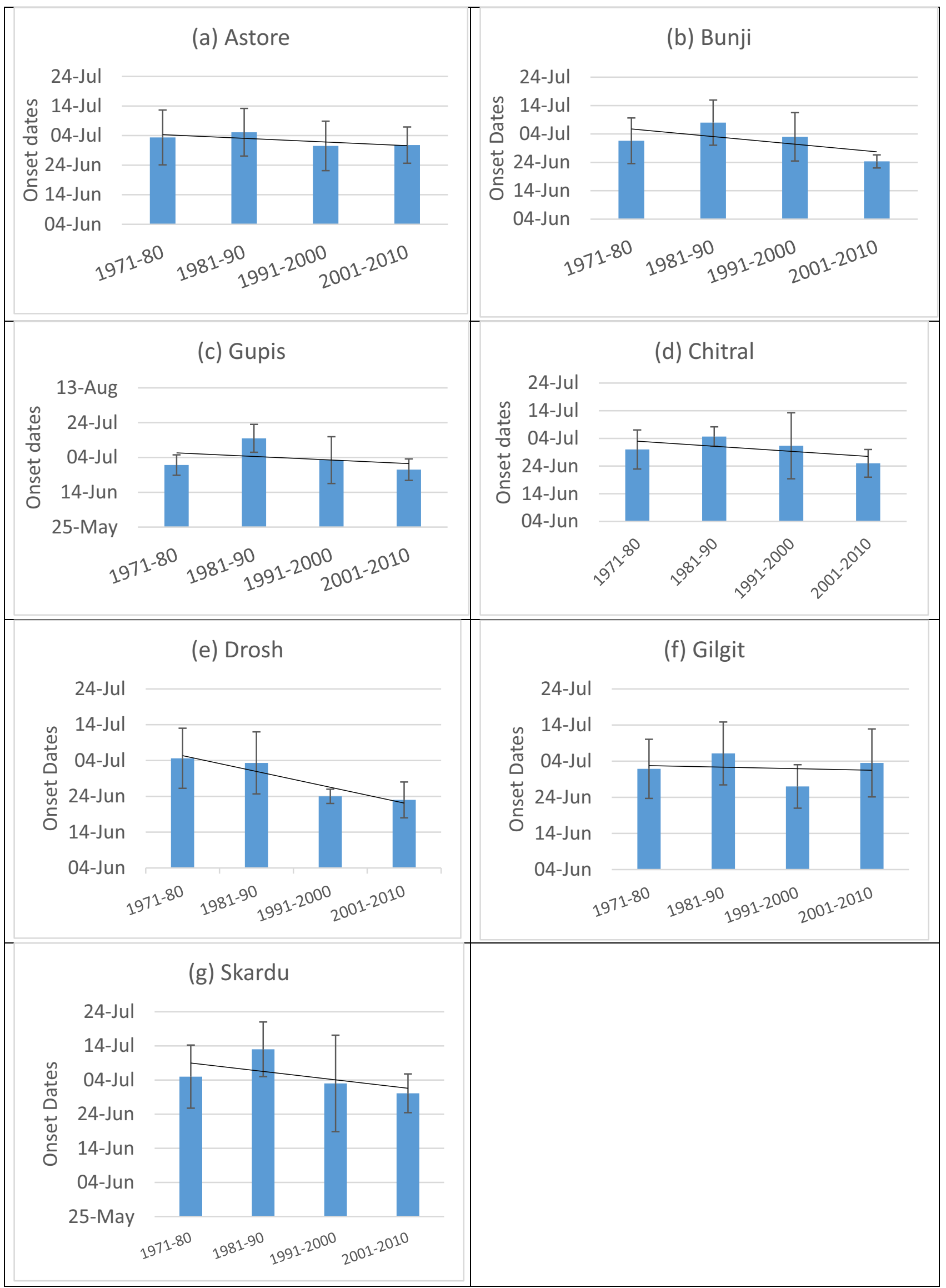

Fig. 12 Trend of monsoon onset over individual stations of north region (Region I) 


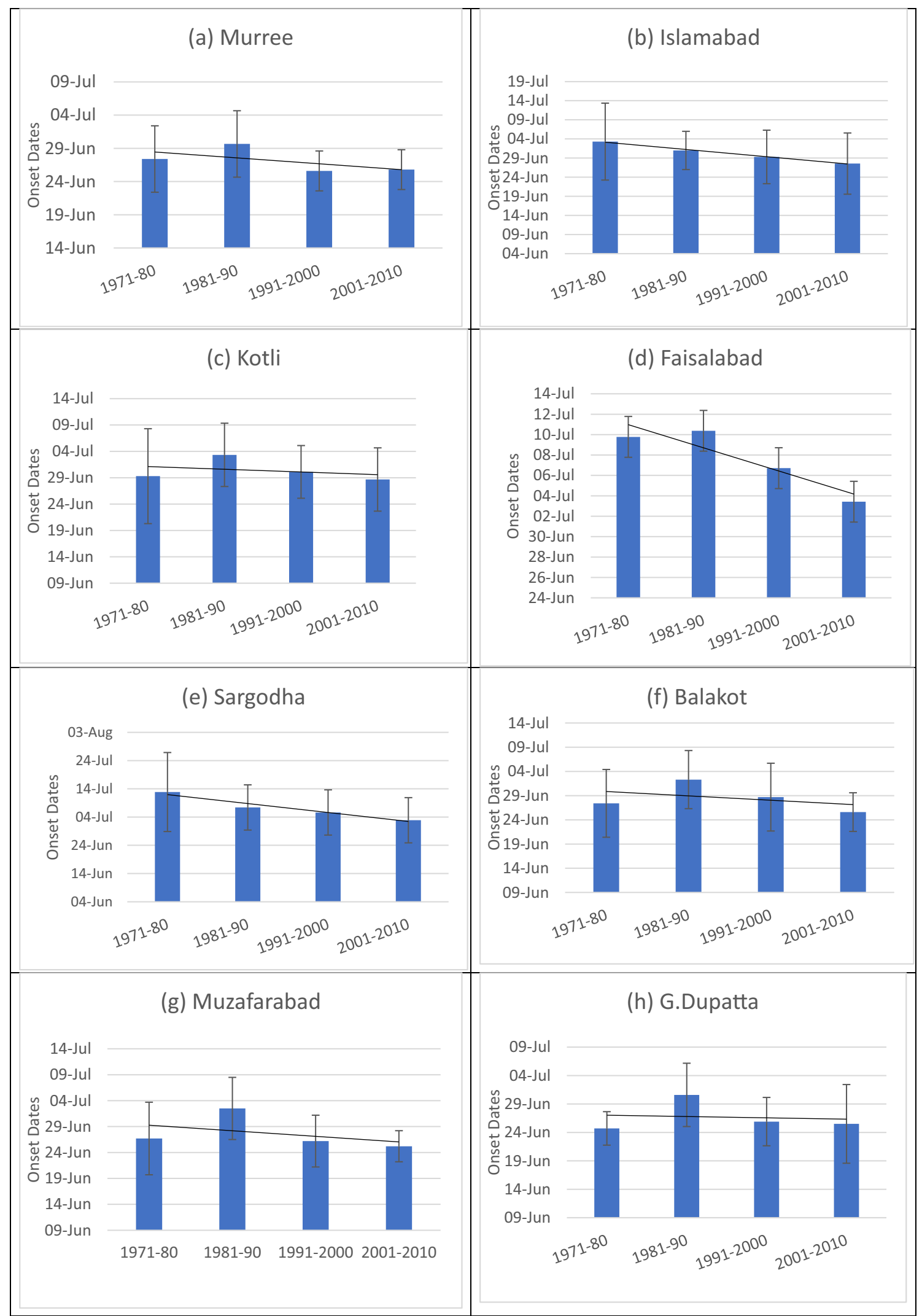

Fig. 13 Trend of monsoon onset over individual stations of central east region (Region II) 


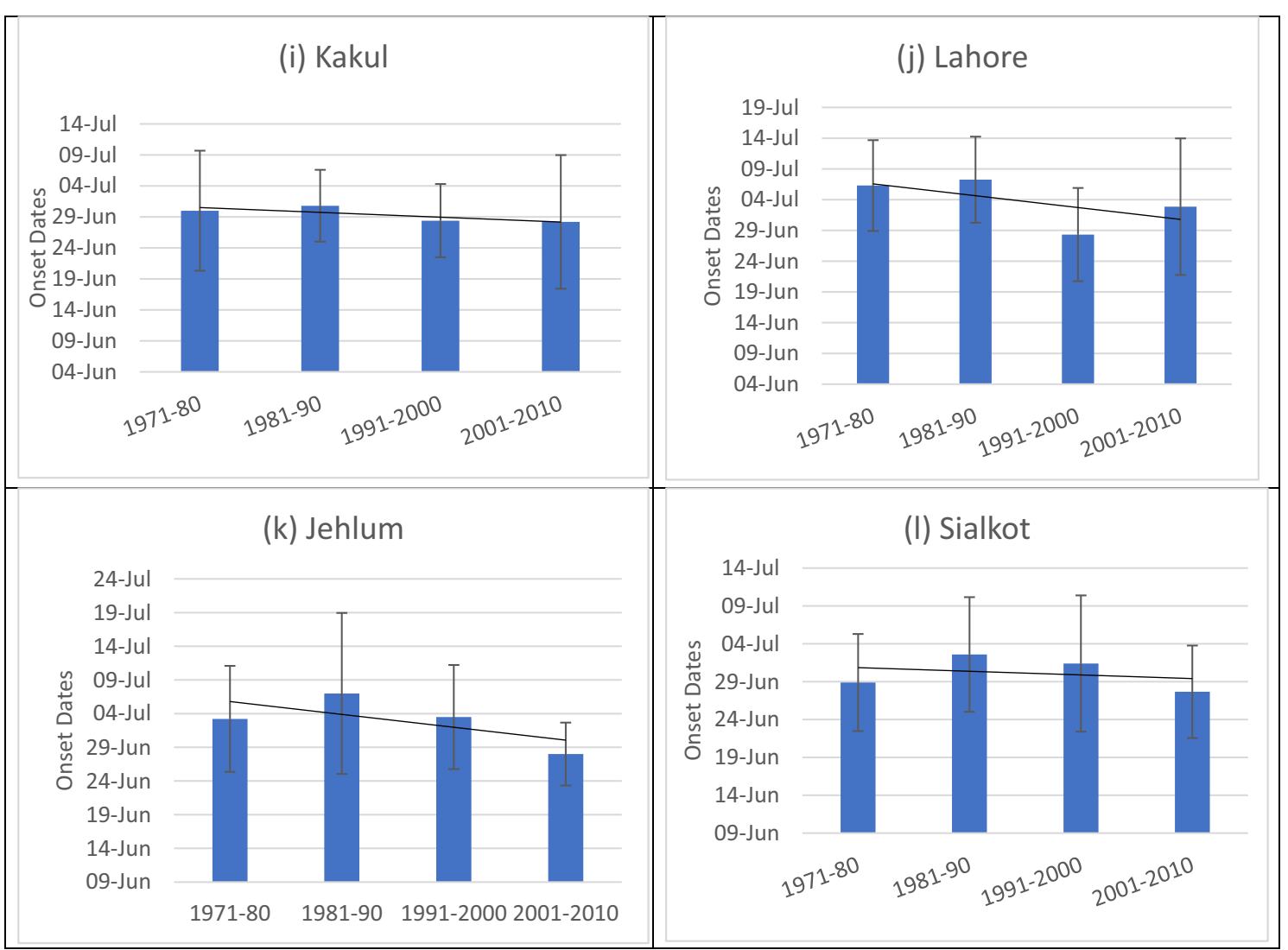

Fig. 13 (continued)

event like ENSO. It is evident from the scientific literature that a worst Asian drought occurred during 1987 (Kumar and Dassai 2004), which is attributed to the strong ENSO year. Also, various studies provide the connection of delayed onset of monsoon with El Nino event. Zhou and Chan (2007) indicated that in the years associated with warm El Nino event, the monsoon tends to have a delayed onset.

The study conducted by Latif et al. (2016) indicates that the highest rainfall area of $200 \mathrm{~mm} / \mathrm{month}$ is observed over CMRP which is also evident from the spatial analysis of rainfall during onset time carried out in current study. In fact, this high rainfall zone is mostly affected by the penetration of monsoon currents resulting from the depressions/low pressure systems travelling west and north-westward from Bay of Bengal (Faisal and Sadiq 2012). As pointed out by Rahmatullah (1952), monsoon rainfall hardly approaches western Pakistan (Baluchistan Province), except when westward moving depressions from Bay of Bengal occasionally recurves toward this region, therefore the amount of precipitation is low in these areas. The low amount of precipitation in these areas is because of Arabian Sea branch of monsoon (Imran et al. 2014).
Pakistan receives the summer monsoon rainfall through two different systems; first from Bay of Bengal, the south westerly winds strike the Himalayas and enters Pakistan after deflecting and travelling along the foothill of Himalayas while second is the southwest winds that enter south Pakistan from the Arabian Sea. The Region I and II comprise the north-eastern belt of monsoon in Pakistan where Sialkot, Jhelum, Islamabad and Lahore stations lie that receive first monsoon rainfall from these currents and make the north-eastern belt of summer monsoon, therefore, show an earlier onset at the end of June. After Region II, the winds penetrate the Region III which experiences monsoon onset later and hence shows an onset in start of July. Region IV receives monsoon partially from a weakened northeastern belt and partially from south-western winds which is developed later and cause the onset in the start of July.

The spatial analysis done in this study has shown that the amount of precipitation has decreased in all regions over the course of four decades, with least amount of precipitation is received during the decade of 1981-1990. Latif et al. (2016) has also indicated significant weakening trends of seasonal mean rainfall over the south Asian region during monsoon season for 




Fig. 14 Trend of monsoon onset over individual stations of central west region (Region III)

the period of 1951-2012 using CRU data sets. Similarly, a study by Singh and Sen (2002) found decreasing trend of summer monsoon rainfall from 1964 to 1992 in Beas River catchment. Moreover, the drought occurred during the 1980 's might be a reason of less amount of precipitation during the decade of 1981-1990. The results show that the area with highest amount of mean precipitation seems to be shrinking over the period of four decade which agrees with the study carried out by Hanif et al. (2013). Hanif et al. (2013) stated that the extreme monsoon rainfall was observed shifting away from the eastern boundary towards the north-western part of Pakistan. Our results show that the drier condition in the parts of Sindh and Baluchistan Provinces which have been indicated by Hanif et al. (2013), are showing the decreasing precipitation trend in southern part of Pakistan as well as along the coastal belt and parts of Sindh Province.

Hence, understanding the spatio-temporal distribution of precipitation during the monsoon period is essential to water resource management in Pakistan, such as flood management, flood mitigation, water conservation, and irrigation system. 


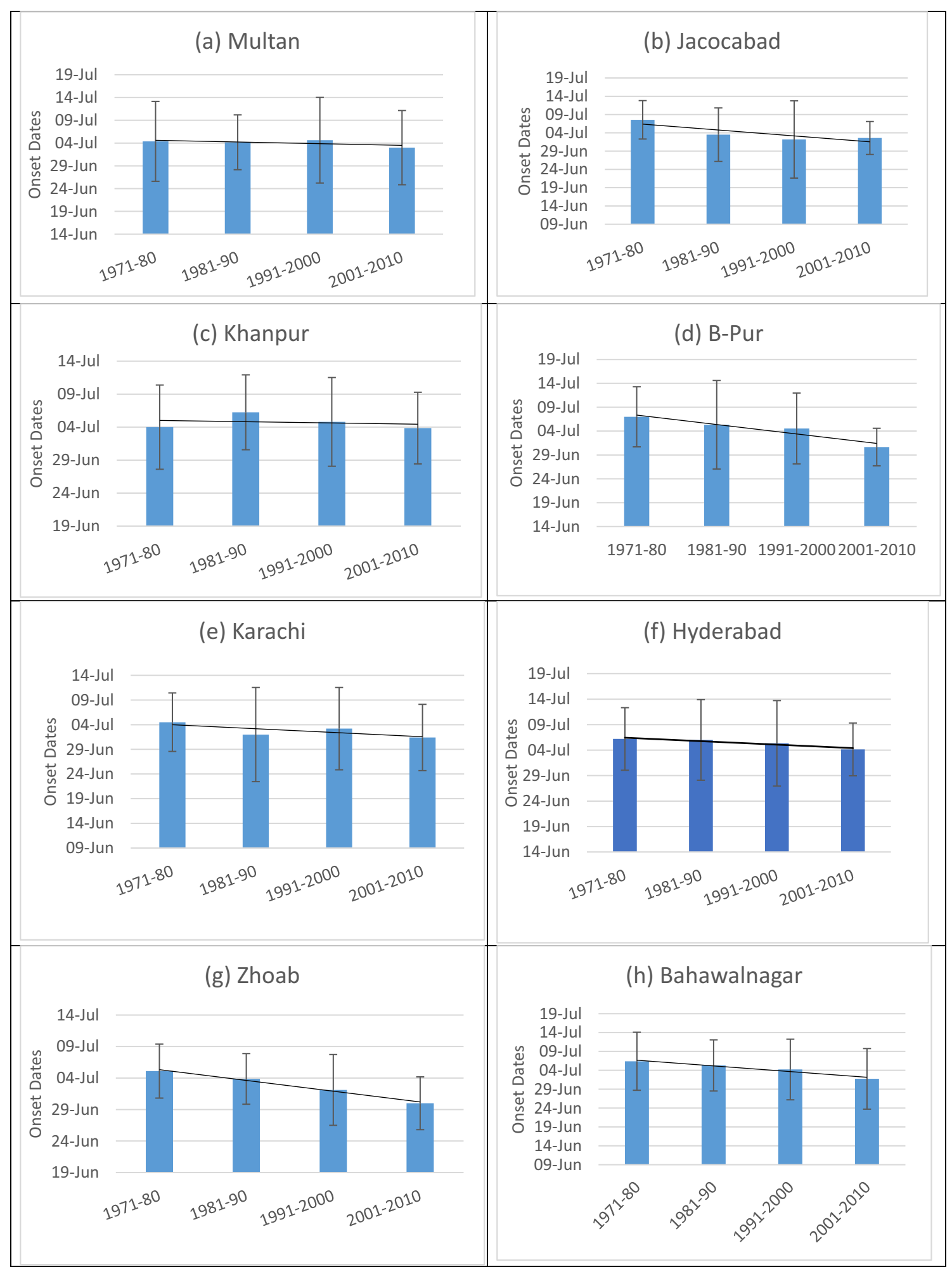

Fig. 15 Trend of monsoon onset over individual stations of southern region (Region IV)

As the economy of Pakistan is highly supported from the agriculture sector, the occurrence of monsoon rainfall (from June-September) is very important. The accurate prediction of space-time precipitation in Pakistan provides useful information for decision making in the management of water resources (Bates et al. 2008). 
Fig. 16 Average of summer monsoon rainfall for stations falling in the Regions I, II and III

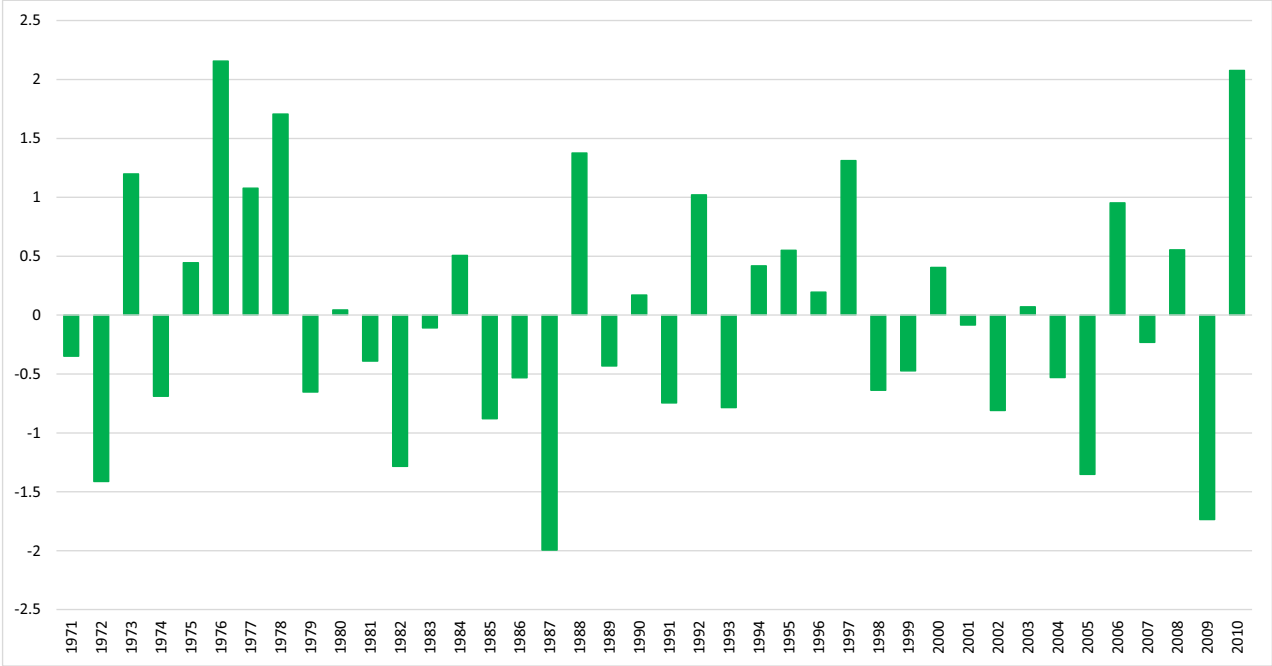

Fig. 17 Average of summer monsoon rainfall for stations falling in the Region IV
Fig. 18 Average of summer monsoon rainfall for stations in all the four regions and standard deviation
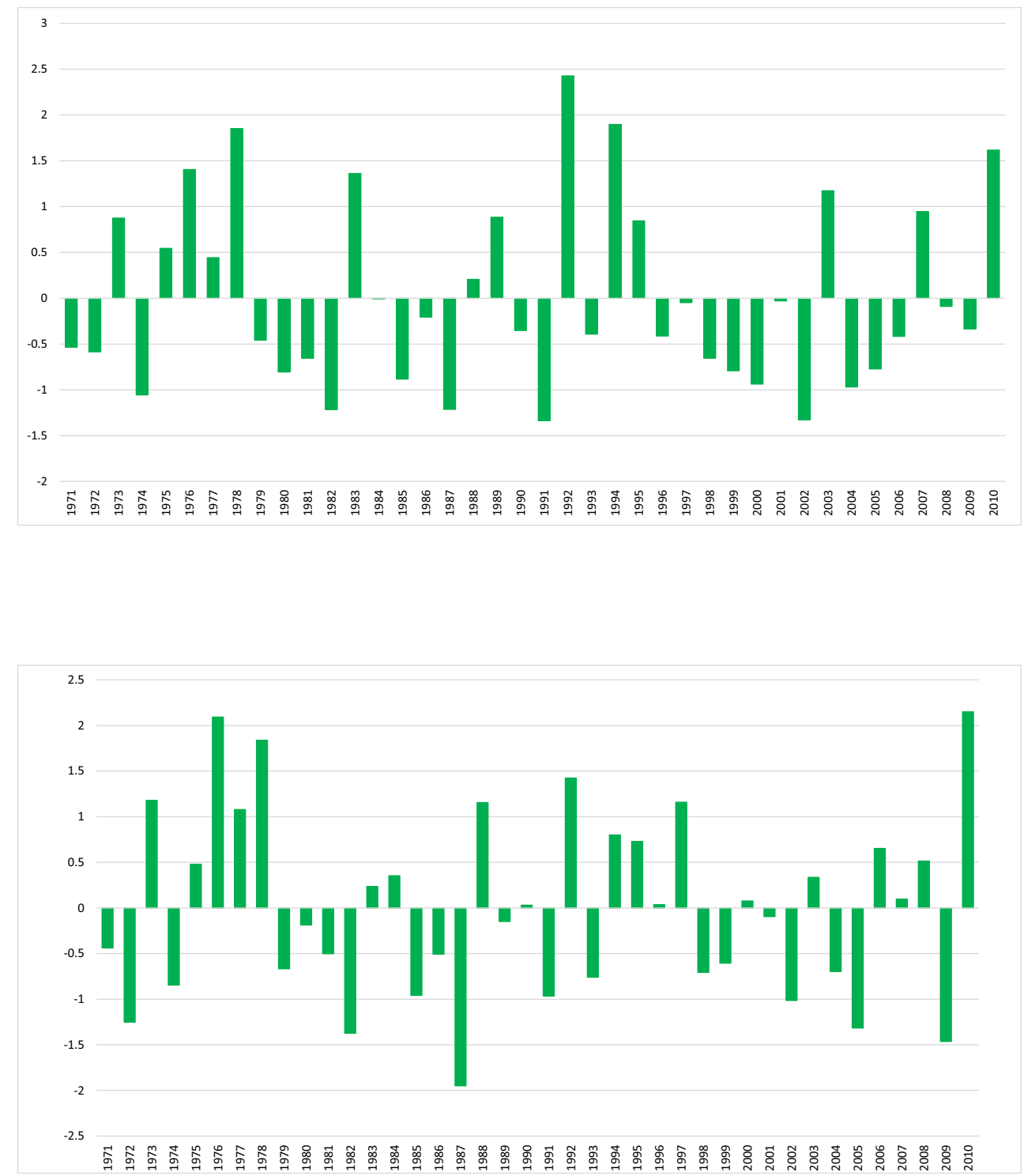


\section{Conclusion}

This study provides a detailed insight to the monsoon onset over Pakistan from 1971 to 2010. In the present study conclusion has been drawn based on statistical analysis of precipitation data obtained from 35 weather stations located all over Pakistan. Analysis of 40 years of data revealed variations in the time of summer monsoon onset over Pakistan. The temporal analysis shows that monsoon onset has an earlier shift in Pakistan region. Although there are certain factors which effect the monsoon system such as ENSO that has caused a delay in the monsoon onset during the decade of 19811990. Therefore, the mean monsoon onset over 40 years has a shift to an earlier time in the whole region.

Spatial analysis in this study revealed the decreasing trend in total amount of precipitation in all regions within defined time period of 20th June-20th July, over the course of four decades. Region II received highest amount of precipitation among all regions whereas the Region IV is deprived of plentiful and enough rainfall. Winds from Arabian Sea bring precipitation in the southern part of the country and it is evident from the study that in 1970's there was a significant amount of precipitation in the region although the area receiving the precipitation was quite smaller. Over the course of these four decades that smaller area is diminishing. The overall decreasing trend in precipitation can be attributed to impacts of climate change.

Pakistan is an agricultural country with cropping pattern largely dependent on monsoon rainfall. The results obtained in this study will help in predicting and investigating the future scenario of rainfall and monsoon weather system which is a life line for agriculture in Pakistan. Therefore, accurate prediction of monsoon onset will help to manage the agricultural issues in an efficient way. In order to understand recent trends in temporally shifted prolonged monsoon and spatially occurring rainfalls in Pakistan, it is necessary to explore trends in precipitation over the regions prone to environmental changes. Moreover, a better understanding of precipitation patterns will be helpful for the future planning in terms of water availability and utilization in various fields most importantly for power generation and irrigation purposes.

Acknowledgments Open access funding provided by International Institute for Applied Systems Analysis (IIASA). We acknowledge Global Change Impact Studies Center, Islamabad, Pakistan for its support in performing analysis.

Open Access This article is distributed under the terms of the Creative Commons Attribution 4.0 International License (http:// creativecommons.org/licenses/by/4.0/), which permits unrestricted use, distribution, and reproduction in any medium, provided you give appropriate credit to the original author(s) and the source, provide a link to the Creative Commons license, and indicate if changes were made.

\section{References}

Ahmad, I., Mahmood, I., Malik, I.R., Arshad, I.A., Haq, E.I., Iqbal, Z.: Probability analysis of monthly rainfall on seasonal monsoon in Pakistan. Int. J. Climatol. 34, 827-834 (2014)

Ananthakrishnan, R., Soman, M.K.: The onset of the south-west monsoon over Kerala.1901- 1980. J. Clim. 8, 283-296 (1988)

Bates, B.C., Kundzewicz, Z.W., Wu, S., Palutikof, J.P.: Climate Change and Water, Technical paper of the Intergovernmental Panel on Climate Change, p. 210 (2008)

Bhat, G.S., Chakraborty, A., Nanjundiah, R.S., Srinivasan, J.: Vertical thermal structure of the atmosphere during active and weak phases of convection over the north bay of Bengal: observation and model results. Curr. Sci. 83, 296-302 (2002)

Bryson, R.A., Murray, T.J.: Climates of Hunger: Mankind and the world's Changing Weather. University of Wisconsin Press, Madison (1977)

Chang, C.K., Ghani, A., Puay, H.T., Othman, M.A.: Homogeneity testing and trends analysis in long term rainfall data for Sungai Pahang River Basin over 40 years records. Proceedings of the 37th IAHR World Congress. Kuala Lumpur, Malaysia (2017)

Compendium of Meteorology.: Editor Aksel, W.N. Volume II, Part 4 Tropical meteorology, prepared by Krishnamurti, T.N. World Meteorological Organization, Geneva, Switzerland (364), 238 (1979)

Cook, B.I., Buckley, B.M.: Objective determination of monsoon season onset, withdrawal, and length. J. Geoph. Res. 114, D23109 (2009)

Das, S.K., Deb, S.K., Kishtawal, C.M., Pal, P.K.: Seasonal prediction of Indian summer monsoon: sensitivity to persistent SST. J. Earth Syst. Sci. 122(5), 1183-1193 (2013)

Ding, Y.H., Chan, C.L.: The east Asian summer monsoon: an overview. Meteor. Atoms Phys. 89, 117-142 (2005)

Ding, Y., Sikka, D.R.: Synoptic systems and weather. In: Wang, B. (ed.) The Asian Monsoon, pp. 131-201. Springer, Berlin (2006)

ESRI-Make predictions overview-Analytics | ArcGIS Desktop.: Environmental Systems Research Institute ESRI. http://desktop. arcgis.com/en/analytics/case-studies/overview-of-makepredictions.htm (2017). Accessed on 22 December 2017

Faisal, N., Sadiq, N.: Monsoon onset over selected eastern boundary cities of Pakistan. Nucleus. 49, 239-245 (2012)

Fasullo, J., Webster, P.J.: A hydrological definition of Indian monsoon onset and withdrawal. J. Clim. 16(19), 3200-3211 (2003)

Hanif, M., Khan, A.H., Adnan, S.: Latitudinal precipitation characteristics and trends in Pakistan. J. Hyd. 492, 266-272 (2013)

Imran, A., Zaman, Q., Rasul, G., Mahmood, A.: An analytical study of the variations in the monsoon patterns over Pakistan. Pak. J. Met. 10(20), 25-37 (2014)

India Meteorological Department (IMD): Climatological Atlas for Airmen. India Meteorological Department, New Delhi (1943)

Intergovernmental Panel on Climate Change-IPCC: Contribution of working group II to the fifth assessment report of the intergovernmental panel on climate change, pp. 1327-1370. Cambridge University press, Cambridge, and New York (2014)

IUCN: Nepal. Proceeding, workshop on 'stabilizing climate change in the Himalayas' (2009)

Johnson, R.H., Ciesielski, H.P., Keenan, T.D.: Oceanic east Asian monsoon convection: results from the 1998 SCSMEX. In: The East Asian Monsoon. Ed. by C. P. Chang. World Scientific, Singapore, 436-459 (2004)

Joseph, P.V., Sooraj, K.P., Rajan, C.K.: The summer monsoon onset process over south Asia and an objective method for the date of monsoon onset over Kerala. Int. J. Climatol. 26, 1871-1893 (2006)

Kang, H.M., Yusof, F.: Homogeneity tests on daily rainfall series in peninsular Malaysia. Int. J. Contemp. Math. Sci. 7, 9-72 (2012) 
Karabork, M.C., Kahya, E., Komuscu, A.U.: Analysis of Turkish precipitation data: homogeneity and the southern oscillation forcings on frequency distributions. Hydr. Proc. 21, 3203-3210 (2007)

Krishnamurti, T.N.: Summer Monsoon experiment-a review. Mon. Wea. Rev. 113, 1590-1626 (1985)

Kumar, R., Dassai, P.: A new criterion for identifying breaks in monsoon conditions over the Indian subcontinent. Geoph. Res. Lett. 31(1-4), (2004)

Kumar, M.R.R., Sankar, A., Reason, C.: An investigation into the conditions leading to monsoon onset over Kerala. Theor. App. Clim. 95(1-2), 69-82 (2009)

Lai, M., Whettori, P.H., Pittodi, A.B., Chakraborty, B.: The greenhouse gas induced climate change over the Indian sub-continent as projected by GCM model experiments. Terr. Atmos. Oce. Sci. 9(663-669), (1998)

Latif, M., Syed, F.: Determination of summer monsoon onset and its related large-scale circulation characteristics over Pakistan. Theor. App. Clim. 125, 509-520 (2015)

Latif, M., Syed, F.S., Hannachi, A.: Rainfall trends in the south Asian summer monsoon and its related large-scale dynamics with focus over Pakistan. Clim. Dyn. 48, 3565-3581 (2016)

Lau, K.M., Ding, Y.H., Wang, J.T., Johnson, R., Keenan, T., Cifelli, R., Gerlach, J., Thiele, O., Rickenbach, T., Tsay, S.C., et al.: A report of the field operation and early results of the South China Sea Monsoon experiment (SCSMEX). Bull. Amer. Meteor. Soc. 81, 1261-1270 (2000)

Pai, D.S., Nair, R.M.: Summer monsoon onset over Kerala: new definition and prediction. J. Earth. Syst. Sci. 118(2), 123-135 (2009)

Peterson, T.C., Easterling, D.R., Karl, T.R., Groisman, P., Nicholls, N., Plummer, N., Torok, S., Auer, I., Boehm, R., Gullett, D., Vincent, L., Heino, R., Tuomenvirta, H., Mestre, O., Szentimrey, T., Salinger, J., Forland, E., Hanssen-Bauer, I., Alexandersson, H., Jones, P., Parker, D.: Homogeneity adjustments of in situ atmospheric climate data: a review. Int. J. Climatol. 18, 1493-1517 (1998)

Pettitt, A.N.: A non-parametric approach to the change point problem. J. App. Stat. 28, 126-135 (1979)

Preethi, B., Mujumdar, M., Kripalani, R.H., Prabhu, A., Krishnan, R.: Recent trends and tele-connections among south and east Asian summer monsoon in a warming environment. Clim. Dyn. 48, 2489-2505 (2017)

Puranik, S.S., Ray, K.S., Sen, P.N., Kumar, P.P.: An index for predicting the onset of monsoon over Kerala. Curr. Sci. 105(7), 954-961 (2013)

Rahmatullah, M.: Synoptic aspects of the monsoon circulation and rainfall over indo-Pakistan. J. Met. 9, 176-179 (1952)

Raju, P.V.S., Mohanty, U.C., Bhatla, R.: Onset characteristics of the southwest monsoon over India. Int. J. Climatol. 25(2), $167-182(2005)$
Rashid, K., Rasul, G.: Rainfall variability and maize production over the Potohar plateau of Pakistan. Pak. J. Met. 8, 63-74 (2011)

Rasul, G., Chaudhry, Q.Z.: Review of advance in research on Asian summer Monsoon. Pak. J. Met. 6(12), 1-10 (2010)

Sadiq, N., Qureshi, M.S.: Climatic variability and linear trend models for the five major cites of Pakistan. J. Geogr. Geol. 2(1), 83-92 (2010)

Saeed, S., Müller, W.A., Hagemann, S., Jacob, D., Mujumdar, M. and Krishnan, R.: Precipitation variability over the South Asian monsoon heat low and associated teleconnections. Geophys. Res. Lett. 38, (2011). https://doi.org/10.1029/2011GL046984

Sahana, A.S., Ghosh, S., Ganguly, A., Murtugudde, R.: Shift in Indian summer Monsoon onset during 1976-1977. Env. Res. Lett. 10(5), 054006 (2015)

Shah, M.A., Zeb, A., Mahmood, S.: In: Met, P.J. (ed.) The Rainfall Activity and Temperatures Distribution over KPK during the Monsoon Season (July to September) 2009, vol. 8, pp. 43-69 (2012)

Shamshad, K.: Predicting Stream Flow and Sediment Yield for Mountainous Areas in Northern Pakistan. Ph.D. degree in Watershed Science. Utah State University (1988)

Simon, B., Rahman, S.H., Joshi, P.C.: Conditions leading to the onset of the Indian monsoon: a satellite perspective. Met. Atmos. Phys. 93(3-4), 201-210 (2006)

Singh, N., Ranade, A.A.: Determination of Onset and Withdrawal Dates of Summer Monsoon across India Using NCEP/NCAR re-Analysis. Research Report No. RR-124. Indian Institute of Tropical Meteorology, Pune-411 008, India (2010)

Singh, R.B., Sen, R.S.: Climate variability and hydrological extremes in a Himalayan catchment. ERB and Northern European FRIEND Project 5 Conf., Slovakia (2002)

Smadi, M., Zghoul, A.: A sudden change in rainfall characteristics in Amman, Jordan during the mid-1950s. J. Env. Sci. 2, 84-91 (2006)

Wang, B., Ding, Q., Joseph, P.V.: Objective definition of the Indian summer Monsoon onset. J. Clim. 22(12), 3303-3316 (2009)

Webster, P.J.: Oceans and monsoons, In The Global Monsoon System: Research and Forecast. Ed. by Chang, C. P., Wang, B., Lau, N.C.G., WMO/TD NO.1266, 253-298 (2005)

Webster, P.J., Lukas, R.: The coupled ocean-atmospheric response experiment. Bull. Amer. Meteor. Soc. 73, 1377-1416 (1992)

Wijngaard, J.B., Klein, A.M.G., Konnen, G.P.: Homogeneity of 20th century European daily temperature and precipitation series. Int. J. Climatol. 23, 679-692 (2003)

Zhou, W., Chan, J.C.I.: ENSO and the South China Sea summer monsoon onset. Int. J. Climatol. 27, 157-167 (2007)

Publisher's Note Springer Nature remains neutral with regard to jurisdictional claims in published maps and institutional affiliations. 